\title{
Dendrobium: Sources of Active Ingredients to Treat Age- Related Pathologies
}

\author{
Veronika Cakova $^{1, *}$, Frederic Bonte ${ }^{2}$, Annelise Lobstein ${ }^{1}$ \\ ${ }^{1}$ Université de Strasbourg, CNRS, LIT UMR 7200, F-67000 Strasbourg, France \\ ${ }^{2}$ LVMH Recherche, F-45800 Saint Jean de Braye, France
}

[Received December 31, 2016; Revised February 13, 2017; Accepted February 14, 2017]

\begin{abstract}
Dendrobium represents one of the most important orchid genera, ornamentally and medicinally. Dendrobiums are sympodial epiphytic plants, which is a name they are worthy of, the name coming from Greek origin: "dendros", tree, and "bios", life. Dendrobium species have been used for a thousand years as first-rate herbs in traditional Chinese medicine (TCM). They are source of tonic, astringent, analgesic, antipyretic, and anti-inflammatory substances, and have been traditionally used as medicinal herbs in the treatment of a variety of disorders, such as, nourishing the stomach, enhancing production of body fluids or nourishing Yin. The Chinese consider Dendrobium as one of the fifty fundamental herbs used to treat all kinds of ailments and use Dendrobium tonic for longevity. This review is focused on main research conducted during the last decade (2006-2016) on Dendrobium plants and their constituents, which have been subjected to investigations of their pharmacological effects involving anticancer, anti-diabetic, neuroprotective and immunomodulating activities, to report their undeniable potential for treating age-related pathologies.
\end{abstract}

Key words: Dendrobium, aging, anticancer, immunomodulatory, neuroprotective, anti-diabetic

Orchidaceae is the largest botanical family of flowering plants. Among about 27,800 orchid species, Dendrobium represents one of the most important genera, ornamentally and medicinally. With more than 1,500 species (www.theplantlist.org), Dendrobium is the second largest orchid genus after Bulbophyllum, widely distributed throughout Asia, Europe and Australia. Dendrobiums are sympodial epiphytic plants, which is a name they are worthy of, the name coming from Greek origin: "dendros", tree, and "bios", life. In Japan, since the Antiquity, Dendrobium moniliforme ("Fu-ran") has been known as "the orchid that gives long life to men". Dendrobium species have been used for a thousand years as first-rate herbs and a prized folk medicine in India and China [1]. In traditional Chinese medicine (TCM), they are source of tonic, astringent, analgesic, antipyretic, and anti-inflammatory substances, and have been traditionally used as medicinal herbs in the treatment of a variety of disorders, such as, nourishing the stomach, enhancing production of body fluids or nourishing Yin. A common name "Shihu" is used for thirty Dendrobium species $(D$. nobile, $D$. chrysotoxum, D. fimbriatum and other related Dendrobium species) or "Tiepi shihu" for D. officinale. About seventy Dendrobium species are found in China, but only two monographs are found in Chinese Pharmacopoeia (2010 edition) [2].

In light of their traditional importance as medicinal plants, knowledge on the constituents of various Dendrobium species and their pharmacological activities has been growing, and methodologies have been

*Correspondence should be addressed to: Dr. Veronika Cakova, University of Strasbourg, Faculty of Pharmacy, UMR 7200, 67400 Illkirch Graffenstaden, France. E-mail: cakova@unistra.fr

Copyright: () 2017 Cakova et al. This is an open-access article distributed under the terms of the Creative Commons Attribution License, which permits unrestricted use, distribution, and reproduction in any medium, provided the original author and source are credited. 
developed for the effective propagation of members of this genus or for the authentication of Dendrobium drugs from its adulterants [3, 4]. In fact, the Chinese consider Dendrobium as one of the fifty fundamental herbs used to treat all kinds of ailments and use Dendrobium tonic for longevity $[2,3]$. Indeed, a large number of pharmacological activities were assigned to different Dendrobium species, such as anti-inflammatory [5], antiplatelet aggregation [6], hepatoprotective [7], anti-fibrotic [8], anti-viral [9], anti-fungal [10], antimicrobial [11], antioxidant [12-14], anti-diabetic [15], neuroprotective [16], immunomodulatory and anticancer [17]. The scientific literature reports various studies on extracts from Dendrobium plants, as well as on their isolates. The most active constituents are polysaccharides, phenanthrene derivatives and alkaloids [16, 18, 19].

Aging is a normal physiological process, which represents the accumulation of changes in human organisms. Thanks to scientific progress and awareness of factors related to life style, the population is becoming older. The other side of the coin is that aging is one of the most important risk factor for the break out of many human diseases and people die from age-related disorders [20]. Aging successfully became a research and public health priority for the $21^{\text {st }}$ century [21]. In this context, researchers worldwide have been focusing their investigations on mechanisms involved in aging, especially in its related pathologies. The ones, which are often explored, are cancer, neurodegenerative diseases and diabetes mellitus as they are widely associated to elderly. Moreover, aging can be examined from an immunological point of view, because it is generally accepted, that the immune system does not work as well as we grow older and becomes altered with age. Therefore, the disturbed and weakened immunity can be a cause of disease among elderly [22].

Knowing that Dendrobium drugs have been traditionally used in TCM preparations as a universal remedy, they are worth investigating by scientists who are looking for new natural ingredients, which could become a main feature in healthy aging. This review is focused on the main research conducted during the last decade (20062016) on Dendrobium plants and their constituents, which have been subjected to investigations of their pharmacological effects involving cancer-related, antidiabetic, neuroprotective and immunomodulating activities, in search for new ingredients to treat age-related pathologies.

\section{Anticancer effects}

In the search of new strategies for fighting cancer, Dendrobium species as well as their isolates, have been studied as a valuable natural source of promising anticancer agents. Due to the high diversity of types of cancer, specific mechanisms of action have been explored to assign to Dendrobium spp. cytotoxic, anti-proliferative, anti-metastatic, antitumor, anti-genotoxic, antimigratory or apoptotic properties in vitro or in vivo and suggest their potential anticancer effects. Recently, D. candidum methanolic extract (DCME) was investigated for these effects on colon cancer. In vitro, HCT-116 human colon cancer cells were treated with DCME and its cytotoxic effect was evaluated using a MTT assay [23]. At 0.25, 0.5 and $1.0 \mathrm{mg} / \mathrm{mL}$, DCME showed a cancer cell survival rate of $69 \%, 41 \%$ and $16 \%$, respectively, by induction of apoptosis. Even if some studies have showed preliminarily anticancer effects of $D$. candidum, the specific mechanisms have not been fully clarified. Indeed, the cell proliferation is the most important characteristic of the tumor cells and could be indicated by the cell viability. Thus, human breast cancer cell line (MCF-7) and normal breast epithelial cell line MCF10A were used to observe the cell viability and explore the antiproliferative effects of $D$. candidum in vitro [17]. The inhibition of the MCF-7 cell viability by enhancing the cell cycle arrest in G2/M phase and regulating the key biomarkers (tumor growth-associated biomarkers, including Era, 1GPBP2, IGFBP4, GATA3, and apoptosis-associated biomarkers, including ELF5, p53, p21, p18, CDH1, CDH2, and p12) in breast cancer cells was demonstrated. In addition, treatment with $D$. candidum at any concentration and any time point caused no inhibitory effect on cell proliferation of MCF10A cell line, suggesting its selectivity against MCF-7 breast cancer cell proliferation. Dendrobium formosum leaf ethanolic extract showed antitumor activity on T-cell (Dalton's) lymphoma. In vitro, the extract induced cytotoxic response in a concentration-dependent manner, with an $\mathrm{IC}_{50}$ value at $350 \mu \mathrm{g} / \mathrm{mL}$, against Dalton's lymphoma (DL) cells [24]. Moretti et al. (2013) assessed anti-genotoxic effect of $D$. speciosum on the liver hepatocellular carcinoma cell line (HepG2) [25]. The stems extract did not induce DNA strand breakage in the range of concentration tested $(2.5-100.0 \mu \mathrm{g} / \mathrm{mL})$, whereas at the higher concentration tested $(100 \mu \mathrm{g} / \mathrm{mL})$ the leaves extract caused a significant increase in the extent of DNA damage, thus indicating a genotoxic effect. However, when testing the D. speciosum stems extract for antigenotoxicity, low doses result in enhanced activity, whereas higher doses result in no effect. Anti-proliferative effects were assigned to alcalase-derived polypeptides of Dendrobium catenatum against human liver (HepG2), gastric (SGC-7901) and breast (MCF-7) cancer cell lines [26]. The best anti-proliferative activity in vitro with a percentage of inhibitions of $73.38 \%, 78.91 \%$ and $86.8 \%$ against HepG2, SGC-7901 and MCF-7 cancer cells, respectively, were obtained at $500 \mu \mathrm{g} / \mathrm{mL}$. The three most abundant peptides (RHPFDGPLLPPGD, RCGVNAFLP 
KSYLVHFGWKLLFHFD and KPEEVGGAGDRWTC, determined by de novo sequencing) were chemically synthesized and their anti-proliferative activities in vitro were also confirmed.

Studies reporting anticancer effects of Dendrobium isolates focus mostly on bibenzyl and phenanthrene derivatives. 3,4,3'-trimethoxy-5,4'-dihydroxybibenzyl (DTB), aloifoll and 5,3'-dihydroxy-3,4-dimethoxybibenzyl, along with a lignin glycoside longicornuol A, from $D$. sinense showed different degrees of cytotoxicity on SGC-7901, human hepatoma (BEL-7402) and chronic myelogenous leukemia (K562) cell lines. The three bibenzyls were cytotoxic against SGC-7901 ( IC $_{50}$ from $7.8 \pm 0.05$ to $16.7 \pm 0.4 \mu \mathrm{M}$ ), while longicornuol $\mathrm{A}$ was more cytotoxic against BEL-7402 ( IC $_{50} 10.0 \pm 0.4 \mu \mathrm{M}$ ) and K562 (10.3 $\pm 0.1 \mu \mathrm{M})$ [27]. Chaotham et al. (2014) focused their studies on 4,5,4'-trihydroxy-3,3'dimethoxybibenzyl (TDB) from Dendrobium ellipsophyllum and its antimetastatic effect on lung cancer cells (H292) [28]. TDB inhibited epithelial-to-mesenchymal transition and sensitization of lung cancer cells to anoikis. Apoptosis induced by cell detachment was increased in TDB-treated cells and the formation of tumor in anchorageindependent growth was found to be reduced in response to the compound. In a more recent study, it has been demonstrated that the reduction of migration and invasion of H292 cells by TDB was reduced by decreasing migration-regulating proteins, including integrins $\alpha \mathrm{v}, \alpha 4$, $\beta 1, \beta 3$ and $\beta 5$, as well as activated focal adhesion kinase (pFAK), activated Ras-related C3 botulinum toxin substrate 1 (Rac1-GTP) and cell division control protein 42 (Cdc42) [29]. Fourteen bibenzyls and bibenzyl dimers from $D$. fimbriatum were tested for their cytotoxic activity against five human cancer cell lines: human promyelocytic leukemia cells (HL-60), hepatocellular carcinoma cells (SMMC-7721), human alveolar basal epithelial cells (A-549), breast cancer cell line (MCF-7) and colorectal adenocarcinoma cell line (SW480) [30]. Among these bibenzyl derivatives, fimbriadimerbibenzyl A, B, E, F and G exhibited broad-spectrum and moderate cytotoxicity with $\mathrm{IC}_{50}$ values range from 5.85 to 21.23 $\mu \mathrm{M}$. Moscatilin and 4-(3-hydroxy-4-methoxyphenetyl)2,6-dimethoxylphenol were the most cytotoxic compounds with $\mathrm{IC}_{50}$ values range from 2.2 to $12.3 \mu \mathrm{M}$ against all the cell lines, suggesting their tumor inhibitory activity. Amongst other studies on anticancer agents from Dendrobium plants, a $\mathrm{MeOH}$ extract obtained from a whole plant of $D$. brymerianum was evaluated and found to possess significant cytotoxicity against human nonsmall lung cancer $\mathrm{H} 460$ cells, showing $80 \%$ inhibition at a concentration of $50 \mu \mathrm{g} / \mathrm{mL}$ [31]. The investigation of the plant led to the identification of its cytotoxic components and to the determination of their antimigratory activity by wound-healing assay. Moscatilin, gigantol, lusianthridin and dendroflorin exhibited cytotoxic properties $\left(\mathrm{IC}_{50}<\right.$ $200 \mu \mathrm{g} / \mathrm{mL}$ ) and all of them inhibited the migration of the cells across the wound space in a time-dependent manner. Gigantol was the weakest antimigratory agent despite its strong cytotoxicity against H460 cells. During the first $24 \mathrm{hr}$, dendroflorin appeared to be the strongest antimigratory compound. However, after $48 \mathrm{hr}$, moscatilin became the most potent compound, as a result of the substantial increase of its activity during the period of 24$48 \mathrm{hr}$. Moscatilin, isolated for the first time from $D$. moscatum, was also found from Dendrobium pulchellum. Its ability to attenuate migration and invasion in human lung cancer $\mathrm{H} 23$ cells was associated with an attenuation of endogenous reactive oxygen species (ROS), in which hydroxyl radical $(\mathrm{OH} \bullet)$ was identified as a dominant species [32]. Moscatilin from D. pulchellum, together with chrysotobibenzyl, chrysotoxine and crepidatin showed the ability to facilitate anoikis (a form of programmed cell death) and inhibit the growth of lung cancer cells in anchorage-independent condition, thus they disclosed the inhibitory effect on cancer cell metastasis [33]. The effects of moscatilin isolated from $D$. loddigesii were assessed on VEGF and bFGF-induced angiogenesis in cultured human umbilical vein endothelial cells (HUVECs) in vitro and in vivo [34]. It significantly inhibited growth of lung cancer cell line A549 and suppressed growth factor-induced neovascularization. Moreover, VEGF- and bFGF-induced cell proliferation, migration and tube formation of HUVECs was markedly inhibited by moscatilin. Furthermore, this compound was found to induce apoptosis of colorectal cancer HCT-116 cells via tubulin depolymerization and DNA damage stress which leads to the activation of c-Jun NH2-terminal protein kinase and mitochondria-involved intrinsic apoptosis pathway [35]. Moscatilin also inhibits growth and induces apoptosis and mitotic catastrophe in human esophageal cancer cells, including squamous cell carcinoma (SCC) and adenocarcinoma (ADC) derived cell lines [36]. Apoptotic, anti-migratory and cytotoxic properties were also assigned to gigantol, isolated from $D$. draconis, Charoenrungruang et al. (2014) demonstrated the inhibitory effect of gigantol on H292 and H460 cell movement, down-regulation of caveolin-1, activation of ATP-dependent tyrosinase kinase, and cell division cycle 42 , thereby suppressing filopodia formation (in nontoxic doses of 0-20 $\mu \mathrm{M}$ ) [37]. A more recent study demonstrates that gigantol mediates lung cancer cells apoptosis via mitochondrial-dependent mechanism [38]. Moreover, Unahabhokha et al. (2016) demonstrated for the first time that gigantol significantly decreases lung cancer cells viability in a detached condition through anoikis and anchorage-independent assays. Western blotting analysis 
revealed that this compound greatly decreases epithelial to mesenchymal transition (EMT) markers, including Ncadherin, vimentin, and Slug, leading to a significant suppression of protein kinase B, extracellular signalregulated kinase, and caveolin-1 survival pathways during the detached condition [39]. The metastatic behavior of lung cancer cells becomes enhanced when cancer cells undergo EMT. Gigantol has also been reported to possess the ability to suppress EMT in non-small H460 cells by attenuating the activity of ATP-dependent tyrosine kinase, thereby inhibiting the expression of the major EMT transcription factor, Slug, by both decreasing its transcription and increasing its degradation. The inhibitory effects of gigantol on EMT result in a decrease in the level of migration in H460 cells [40]. Erianin, another promising bibenzyl was isolated from the stems of Dendrobium chrysotoxum, a plant used as an antipyretic and analgesic in TCM. The antitumor activity has been investigated in estrogen receptor (ER) positive breast cancer by treating T47D cells with erianin and its effects have been evaluated on multiple cancer-associated pathways [41]. The results showed that erianin significantly decreased the viability of T47D cells at 40, 80 and $160 \mathrm{nM}$ after 24 and 48 hours of treatment. At a concentration of $20 \mathrm{nM}$ after 72 hours of treatment, T47D cells viability was also decreased, demonstrating that the treatment with low dosage over a long time could also inhibit the viability of T47D cells. Interestingly, only a high dose of erianin ( 80 and $160 \mathrm{nM}$ ) could inhibit the proliferation of T47D cells. This study also showed that erianin at low dosages (10 and $20 \mathrm{nM}$ ) could suppress migration of T47D cells effectively. In addition, erianin induced apoptosis in T47D cells through reducing Bcl-2 expression and activating caspase signaling and also suppressed the expression of CDKs and caused cell cycle arrest. Meanwhile, erianin did not affect the proliferation of normal breast epithelial cell line MCF10A. Wang et al. (2016) explored the effects of erianin on osteosarcoma (OS) and further elucidated the underlying molecule mechanisms [42]. The inhibitory effects and cytotoxicity of erianin in OS cells was evaluated on various OS cell lines (143B, MG63.2, Saos2, and CCHO). Results demonstrated that erianin inhibits cell proliferation and induces cell cycle G2/M arrest in OS cells by regulating cell cycle-related proteins. Furthermore, erianin induced cell apoptosis by activating both extrinsic (expression of downstream apoptotic protein Caspase-8) and intrinsic (Caspase-9) pathways. Erianin also induced autophagy via ROS/JNK signaling pathway. Dendrofalconerol A (DF-A), a bis(bibenzyl) from $D$. falconeri, demonstrated the anoikis-sensitizing and antimigratory activities and significantly inhibited the growth of H460 lung cancer cells in anchorage-independent conditions [43]. Moreover, DF-A suppresses migrating cancer cells via
EMT and integrin proteins. The expression of migrationrelated integrins, including integrin beta1 and integrin alpha4 was significantly reduced in response to DF-A treatment $(0.5-5 \mu \mathrm{M})$. Also, DF-A was shown to suppress EMT, as indicated by cadherin switch from N- to Ecadherin and decrease of Snail, Slug and vimentin, revealing thus the potential of DF-A as an anti-metastatic agent [44].

Besides bibenzyls, phenanthrenequinones have also drawn attention from anticancer research. Denbinobin, a 1,4-phenanthrenequinone isolated from the stems of Dendrobium moniliforme, was explored for its antitumor mechanisms. This compound inhibited K562 cell viability in a concentration-dependent manner with an $\mathrm{IC}_{50}$ value of $1.84 \mu \mathrm{M}$, caused $\mathrm{G} 2 / \mathrm{M}$ phase accumulation in a timedependent manner and enhanced tubulin polymerization. Furthermore, denbinobin significantly suppressed the expression of Bcr-Abl and phosphorylation of CrkL, a crucial tyrosinase kinase and an adaptor protein in chronic myeloid leukemia, respectively [45]. Sánchez-Duffhues et al. (2009) investigated antitumor activities of denbinobin and the mechanism involved in Jurkat leukemic cells [46]. This compound inhibits nuclear factor- $\mathrm{\kappa B}$ and induces apoptosis via ROS generation, and that this effect takes place in an MAPK-independent pathway. Its cytotoxicity was also examined in several human cancer cells including SK-Hep-1 hepatocarcinoma cells, SNU-484 gastric cancer cells, and HeLa cervix cancer cells with $\mathrm{IC}_{50}$ values of $16.4,7.9$ and $22.3 \mu \mathrm{M}$, respectively [47]. Moreover, the study revealed that denbinobin inhibits the invasive phenotype of SNU-484 cells suggesting that metalloproteinase (MMP)-2 and MMP-9 may be involved in its anti-invasive activity. A study of Weng et al. (2013) revealed that denbinobin induces human glioblastoma multiforme (GBM) cell apoptosis through $\mathrm{I} \kappa \mathrm{B}$ kinase inactivation, followed by Akt and forkhead in rhabdomyosarcoma dephosphorylation and caspase-3 activation signaling cascade. Treatment of GBM cells with denbinobin (0.1-3 $\mu \mathrm{M})$ reduced cell viability in a concentration-dependent manner. Denbinobin at concentrations of $1 \mu \mathrm{M}$ and $3 \mu \mathrm{M}$ significantly decreased the GBM cell viability by $34.1 \% \pm 3.7 \%$ and $62.7 \% \pm 2.8 \%(n=3)$ [48]. Denbinobin, at the concentration of $10 \mu \mathrm{M}$, prevents chemokine protein CXCL12-induced prostate cancer (PC-3) cell migration by inhibiting Rac1 activity. The inhibition of Rac1 activity prevented also lamellipodial formation [49]. Moniliformediquinone, another phenanthrenequinone from $D$. moniliforme, have been studied for its tumor inhibition in human hormone refractory metastatic prostate cancer (HRMPC). This compound $(3 \mu \mathrm{M})$ was found to be a potential anticancer agent for HRMPC by decreasing cellular glutathione, leading to a DNA damage 
response and cell cycle arrest at the $\mathrm{S}$-phase. Mitochondrial stress also occurs due to moniliformediquinone action through loss of mitochondrial membrane potential and cytochrome c release, which leads to apoptosis [50]. Recently, a bibenzyl-dihydrophenanthrene derivative, named dendrosignatol, together with 3,4-dihydroxy-3,4-dimethoxybibenzyl, dendrocandin B, dendrocandin I and dendrofalconerol A, isolated from the whole plant od Dendrobium signatum, showed appreciable cytotoxic activity against three human cancer cell lines, including breast cancer MDA-23 1, liver hepatocellular carcinoma HepG 2 and colorectal tumor HT-29 cells [51]. Recently, phenanthrene and bibenzyl derivatives were isolated from Dendrobium nobile, together with two new spirodiketones, namely (-)- and (+)-denobilone A. All compounds were tested for cytotoxic activities against HeLa, MCF-7 and A549 cells. However, only (-)- and (+)denobilone A showed moderate inhibitory effects on HeLa, MCF-7, and A459 cells, with $\mathrm{IC}_{50}$ values of 9.8, 9.4 , and $9.9 \mu \mathrm{M}$, respectively. The $\mathrm{IC}_{50}$ values of other compounds higher than $10 \mu \mathrm{M}$ were regarded as inactive [52]. Moderate inhibitory activities against HeLa, MCF7, and A459 were also assigned to lactone derivatives from $D$. nobile, decumbic acids A and B, (-)-decumbic acid, (-)- and (+)-dendrolactone, together with decumbic acid, 4-(3-hydroxyphenyl)-2-butanone, 3-hydroxy-1(3methoxy-4-hydroxyphenyl)-propan-1-one and 3',4',5'trimethoxycinnamyl acetate with IC50 values ranging from 15.3 to $30.0 \mu \mathrm{M}[53]$.<smiles>COc1cc(O)cc(CCc2ccc(OC)c(O)c2)c1</smiles><smiles>COc1cc(CCc2cc(OC)c(O)c(OC)c2)ccc1O</smiles><smiles>COc1ccc(CCc2cc(OC)c(OC)c(OC)c2)cc1O</smiles><smiles>COC1=CC(=O)c2ccc3cc(OC)cc(O)c3c2C1=O</smiles><smiles>COc1cc(=O)c2c(=O)c3c(=O)c(OC)cc(=O)c3ccc2c1=O</smiles><smiles>COc1ccc(CCc2cc(OC)c(O)c3c2C(Cc2ccc(OC)cc2)c2cc(O)c(O)c(OC)c2O3)cc1</smiles>

Figure 1. Chemical structures of main anticancer compounds from Dendrobium spp. 
Table 1. Dendrobium spp. and their constituents with anticancer properties.

\begin{tabular}{|c|c|c|c|c|}
\hline $\begin{array}{l}\text { Dendrobium } \\
\text { species } \\
\text { (organ) }\end{array}$ & $\begin{array}{c}\text { Active molecule/type of } \\
\text { extract }\end{array}$ & Biological target & Activity & Refs. \\
\hline $\begin{array}{l}\text { D. brymerianum } \\
\text { (whole plant) }\end{array}$ & $\begin{array}{l}\text { Methanolic extract } \\
\text { Moscatilin } \\
\text { Gigantol } \\
\text { Lusianthridin } \\
\text { Dendroflorin }\end{array}$ & Human lung cancer cell line H460 & Cytotoxic Antimigratory & [31] \\
\hline $\begin{array}{l}\text { D. candidum } \\
\text { (whole plant) }\end{array}$ & $\begin{array}{l}\text { Methanolic extract } \\
\text { Aqueous extract } \\
\text { Not specified }\end{array}$ & $\begin{array}{l}\text { Human colon carcinoma cell line } \\
\text { HCT-116, BALB/c mice bearing 26- } \\
\text { M3.1 colon carcinoma cells } \\
\text { Azoxymethane- and dextran sulfate } \\
\text { sodium-induced colon carcinogenesis } \\
\text { in C57BL/6 mice } \\
\text { BALB/c mice bearing } 26-M 3.1 \text { cells } \\
\text { Breast cancer cell line MCF-7 }\end{array}$ & $\begin{array}{l}\text { Cytotoxic } \\
\text { Anti-metastatic } \\
\text { Inhibitory } \\
\text { Anti-metastatic } \\
\text { Anti-proliferative, induction of } \\
\text { cell cycle arrest at G2/M phase }\end{array}$ & $\begin{array}{l}{[23]} \\
{[55]} \\
{[54]} \\
{[17]}\end{array}$ \\
\hline $\begin{array}{l}\text { D. catenatum } \\
\text { (whole plant) }\end{array}$ & $\begin{array}{l}\text { Protein extract } \\
\text { Peptides }\end{array}$ & $\begin{array}{l}\text { Human liver cancer cell line HepG2, } \\
\text { human gastric cancer cell line SGC- } \\
7901 \text { and breast cancer cell line MCF-7 }\end{array}$ & Cytotoxic, anti-proliferative & [26] \\
\hline $\begin{array}{l}\text { D. chrysotoxum } \\
\text { (Not specified) }\end{array}$ & Erianin & $\begin{array}{l}\text { Human mammary gland T47D cells } \\
\text { Human osteosarcoma cells } 143 \text { B and } \\
\text { Saos2, BALB/c-nu mice orthotopically } \\
\text { inoculated with 143B cells }\end{array}$ & $\begin{array}{l}\text { Antimigratory, anti-proliferative, } \\
\text { induction of apoptosis and cell } \\
\text { cycle arrest } \\
\text { Induction of G2/M-phase arrest, } \\
\text { apoptosis and autophagy }\end{array}$ & $\begin{array}{l}{[41]} \\
{[42]}\end{array}$ \\
\hline $\begin{array}{l}\text { D. draconis } \\
\text { (stems) }\end{array}$ & Gigantol & Human lung cancer cell line H460 & $\begin{array}{l}\text { Antimigratory, induction of } \\
\text { apoptosis through mitochondrial- } \\
\text { dependent pathway } \\
\text { Induction of anoikis, attenuation } \\
\text { of epithelial to mesenchymal } \\
\text { transition (EMT) }\end{array}$ & $\begin{array}{l}{[37,38]} \\
{[39,40]}\end{array}$ \\
\hline $\begin{array}{l}\text { D. ellipsophyllum } \\
\text { (Not specified) }\end{array}$ & $\begin{array}{l}\text { 4,5,4'-trihydroxy- } \\
\text { 3,3'dimethoxybibenzyl }\end{array}$ & Human lung epithelial cells H292 & $\begin{array}{l}\text { Induction of anoikis, attenuation } \\
\text { of EMT, antimigratory }\end{array}$ & {$[28,29]$} \\
\hline $\begin{array}{l}\text { D. falconeri } \\
\quad \text { (aerial parts) }\end{array}$ & Dendrofalconerol A & Human lung cancer cell line H460 cells & $\begin{array}{l}\text { Antimigratory, induction of } \\
\text { anoikis } \\
\text { Reduction of the expression of } \\
\text { migration-related integrins, } \\
\text { suppression of EMT } \\
\end{array}$ & $\begin{array}{l}{[43]} \\
{[44]}\end{array}$ \\
\hline $\begin{array}{r}\text { D. fimbriatum } \\
\text { (stems) }\end{array}$ & $\begin{array}{l}\text { Fimbriadimerbibenzyl A, B, } \\
\text { E, F, G } \\
\text { Moscatilin } \\
\text { 4-(3-hydroxy-4- } \\
\text { methoxyphenetyl)-2,6- } \\
\text { dimethoxylphenol }\end{array}$ & $\begin{array}{l}\text { Human promyelocytic leukemia cells } \\
\text { HL-60, human hepatocarcinoma cells } \\
\text { SMMC-7721, lung carcinoma cells A- } \\
549 \text {, colon cancer cells SW480, breast } \\
\text { cancer cells MCF-7 }\end{array}$ & Cytotoxic & [30] \\
\hline $\begin{array}{l}\text { D. formosum } \\
\text { (leaves) }\end{array}$ & Ethanolic extract & $\begin{array}{l}\text { T-cell lymphoma (in vitro) } \\
\text { Dalton's lymphoma bearing mice }\end{array}$ & $\begin{array}{l}\text { Cytotoxic, induction of apoptosis } \\
\text { Increase of survival time }\end{array}$ & [24] \\
\hline $\begin{array}{l}\text { D. loddigesii } \\
\text { (Not specified) }\end{array}$ & Moscatilin & $\begin{array}{l}\text { Human umbilical vein endothelial cells } \\
\text { (HUVEC) in vitro } \\
\text { Human lung adenocarcinomic cells } \\
\text { A549 xenograft in nude mice } \\
\text { Human breast adenocarcinoma MDA- } \\
\text { MB-231 cells in vitro and in vivo } \\
\text { metastatic model } \\
\text { HCT-116 in vitro and xenograft model } \\
\text { in vivo } \\
\text { Human esophageal cancer cells } \\
\text { (squamous and adenocarcinoma) }\end{array}$ & $\begin{array}{l}\text { Anti-proliferative, inhibition of } \\
\text { VEGF and bFGF-induced } \\
\text { angiogenesis } \\
\text { Inhibition of growth of A549 } \\
\text { xenograft } \\
\text { Inhibitory and antimigratory } \\
\text { Induction of apoptosis } \\
\text { Growth suppression, induction of } \\
\text { apoptosis }\end{array}$ & $\begin{array}{l}{[57]} \\
{[35]} \\
{[36]}\end{array}$ \\
\hline $\begin{array}{l}\text { D. moniloforme } \\
\text { (stems) }\end{array}$ & $\begin{array}{l}\text { Denbinobin } \\
\text { Moniliformediquinone }\end{array}$ & $\begin{array}{l}\text { Leukemic cells } \\
\text { Human hormone refractory prostate } \\
\text { cancer cells PC-3 and DU-145 }\end{array}$ & $\begin{array}{l}\mathrm{NF}-\kappa \mathrm{B} \text { nuclear factor inhibition } \\
\text { and apoptosis via ROS } \\
\text { generation } \\
\text { Glutathione involved } \\
\text { mitochondria stress and DNA } \\
\text { damage }\end{array}$ & {$[50]$} \\
\hline $\begin{array}{l}\text { D. nobile } \\
\text { (stems) }\end{array}$ & Denbinobin & $\begin{array}{l}\text { Human hepatic adenocarcinoma cells } \\
\text { SK-Hep-1, human gastric cell line }\end{array}$ & Cytotoxic & [47] \\
\hline
\end{tabular}




\begin{tabular}{|c|c|c|c|c|}
\hline & $\begin{array}{l}\text { (+)-denobilone A } \\
(-) \text {-denobilone A } \\
\text { decumbic acid } \\
\text { decumbic acid A } \\
\text { decumbic acid B, } \\
\text { (-)-decumbic acid, } \\
\text { (-)-dendrolactone, } \\
\text { (+)-dendrolactone, } \\
\text { 4-(3-hydroxyphenyl)-2- } \\
\text { butanone } \\
\text { 3-hydroxy-1(3-methoxy-4- } \\
\text { hydroxyphenyl)-propan-1-one } \\
\text { 3',4',5'-trimethoxycinnamyl } \\
\text { acetate }\end{array}$ & $\begin{array}{l}\text { SNU-484 and HeLa cervical cancer } \\
\text { cells } \\
\text { Prostatic carcinoma cells PC-3 } \\
\text { HeLa, MCF-7 and A549 cells }\end{array}$ & $\begin{array}{l}\text { Inhibition of invasion of SNU- } \\
484 \text { phenotype via MMP-2/-9 } \\
\text { expression } \\
\text { Antimigratory } \\
\text { Cytotoxic }\end{array}$ & $\begin{array}{c}{[49]} \\
{[52,53]}\end{array}$ \\
\hline D. officinale & Aqueous extractions & $\begin{array}{l}\text { MNNG-induced gastric tumorigenesis } \\
\text { in rats }\end{array}$ & $\begin{array}{l}\text { Antioxidative effect, modulation } \\
\text { of cytokines related to } \\
\text { tumorigenesis, induction of } \\
\text { apoptosis, chemoprevention for } \\
\text { reducing the risk of gastric } \\
\text { cancer }\end{array}$ & {$[56]$} \\
\hline $\begin{array}{c}\text { D. pulchellum } \\
\text { (stems) }\end{array}$ & $\begin{array}{l}\text { Moscatilin } \\
\text { Moscatilin } \\
\text { Chrysotobibenzyl } \\
\text { Chrysotoxine } \\
\text { Crepidatin } \\
\end{array}$ & $\begin{array}{l}\text { Lung cancer cells } \mathrm{H} 23 \\
\text { Lung cancer cells }\end{array}$ & $\begin{array}{l}\text { Inhibition of cell motility and } \\
\text { invasion via suppression of ROS } \\
\text { Anti-metastatic }\end{array}$ & $\begin{array}{l}{[32]} \\
{[33]}\end{array}$ \\
\hline $\begin{array}{l}\text { D. signatum } \\
\text { (whole plant) }\end{array}$ & $\begin{array}{l}\text { Dendrosignatol } \\
\text { 3,4-dihydroxy-3,4- } \\
\text { dimethoxybibenzyl } \\
\text { Dendrocandin B } \\
\text { Dendrocandin I } \\
\text { Dendrofalconerol A } \\
\end{array}$ & $\begin{array}{l}\text { Human breast cancer cells MDA-231, } \\
\text { liver hepatocellular carcinoma HepG2, } \\
\text { colorectal adenocarcinoma HT-29 cells }\end{array}$ & Cytotoxic & [51] \\
\hline $\begin{array}{l}\text { D. sinense } \\
\quad \text { (whole plant) }\end{array}$ & $\begin{array}{l}\text { 3,4,3'-trimethoxy-5,4'- } \\
\text { dihydroxybibenzyl } \\
\text { Aloifoll } \\
\text { 5,3'-dihydroxy-3,4- } \\
\text { dimethoxybibenzyl } \\
\text { Longicornuol A }\end{array}$ & $\begin{array}{l}\text { Human gastric cancer cells SGC-7901, } \\
\text { human hepatoma cells BEL-7402, } \\
\text { chronic myelogenous leukemia K562 }\end{array}$ & Cytotoxic & [27] \\
\hline $\begin{array}{r}\text { D. speciosum } \\
\text { (stems) }\end{array}$ & Methanolic extract & HepG2 cells & Antigenotoxic & [25] \\
\hline
\end{tabular}

The majority of reported studies deal with in vitro evaluations of potential anticancer effects of crude Dendrobium extracts or isolated compounds. Only few of them were deepened in vivo. Besides the in vitro evaluation of Dendrobium candidum methanolic extract by Zhao et al. (2014), its anti-metastatic effect was also assessed in mice with tumors propagated by 26-M3.1 colon carcinoma cells. DCME was the most effective for inhibition of lung metastasis at a concentration of 200 $\mathrm{mg} / \mathrm{kg}$.[23]. The same in vivo model was used by Li et al. (2014), showing preventive effects of $D$. candidum on the formation of lung metastases. The most marked tumor inhibitory rate of $64.5 \%$ has been showed at a dose of 400 $\mathrm{mg} / \mathrm{kg}$ body weight (b.w.) [54]. Wang et al. (2014) also demonstrated that $D$. candidum is effective in the prevention of chemically-induced colon carcinogenesis in C57BL/6 mice, by increasing the serum SOD level and decreasing the levels of pro-inflammatory cytokines IL-6, IL-12, TNF- $\alpha$ and IFN- $\gamma$ [55]. After in vitro cytotoxicity evaluation of Dendrobium formosum leaf ethanolic extract, the results of the in vivo antitumor activity on Dalton's lymphoma were expressed as a ratio of the median survival days of the treated and control group (T/C) of DL bearing mice. With a treatment of $150 \mathrm{mg} / \mathrm{kg}$ b.w., an effective $\mathrm{T} / \mathrm{C}$ value of $172 \%$ with a significant increase in life span compared to control was obtained. The $\mathrm{T} / \mathrm{C}$ value reduced to $144 \%$ on treating the mice with $175 \mathrm{mg} / \mathrm{kg}$, which indicates that higher dose of treatment with $D$. formosum ethanolic extract may induce toxicity [24]. The effect of Dendrobium officinale water extractions was investigated by oral administration (4.8 and $2.4 \mathrm{~g} / \mathrm{kg}$ ) to the rats of the gastric carcinogenesis model. The study suggests that $D$. officinale could downregulate the expression of malondialdehyde and 8hydroxy-2-deoxyguanosine and up-regulate the activity of glutathione peroxidase as well as IL-2 during Nmethyl-N'-nitro-N-nitrosoguanidine-induced gastric tumorigenesis in rats. D. officinale also reduced the level 
of Activin A, Agrin, IL-1 $\alpha$, intracellular adhesion molecule-1, and tissue inhibitor of matrix metalloproteinase-1 and up-regulated the level of IL-10. The results indicate that $D$. officinale shows antioxidant effects, modulates some cytokines related to tumorigenesis, and induces apoptosis [56]. Only two isolated compounds from Dendrobium plants were evaluated in vivo. Pai et al. (2013) showed the antimigratory and anti-metastatic effects of moscatilin on human breast cancer in an MDA-MB-231 metastatic model. Moscatilin $(100 \mathrm{mg} / \mathrm{kg})$ significantly suppresses breast cancer metastasis to the lungs and reduced the number of metastatic lung nodules and lung weight without causing any toxicity [57]. In the study of Wang et al. (2016), an orthotopic osteosarcoma (OS) model was established by intra-tibial injection of 143B cells to confirm the antitumor effect of erianin in vivo. The mice were injected with erianin $(2 \mathrm{mg} / \mathrm{kg})$ while the control group was injected with 5\% DMSO intraperitoneally every other day for seven times in total. Erianin markedly inhibited growth of OS with no major organ-related toxicity [42].

Given the reported data, phenanthrene derivatives, particularly bibenzyls, seem to be very promising compounds, suggesting anticancer activities (Fig. 1). However, many studies do not investigate more than their cytotoxicity against cancer cell lines in vitro, concluding that it suggests their potential for the development of an anticancer drug (Table 1). To the best of our knowledge, no anticancer treatment from Dendrobium herbs has been fully developed for instance.

\section{Neuroprotective effects}

Neuroprotection is a vast term involving the preservation of neuronal structure and/or function. There are many central nervous system (CNS) disorders including neurodegenerative diseases, brain ischemia, neurotoxin consumption and traumatic brain injury. Ischemic brain injury and neurodegenerative diseases, such as Alzheimer's and Parkinson's diseases, are a problem of growing importance in an aging population. Searching for promising neuroprotective agents aims to prevent or slow disease progression and secondary injuries by slowing the loss of neurons. Despite the fact, that molecular pathways involved in neurodegenerative disorders of CNS are multifaceted and complex, common mechanisms include increased levels in oxidative stress, mitochondrial dysfunction, inflammatory processes or protein aggregation and hyperphosphorylation [16, 58, 59]. Comparing to studies on anticancer effects of Dendrobium herbs, there are only a few which have been focused on neuroprotective effects during the last decade. The reported active substances are alkaloids, bibenzyl derivatives and phenolic glucosides. Dendrobium nobile alkaloids (DNLA) were studied for their effects on rat primary cultured neurons subjected to oxygen-glucose deprivation/reperfusion (OGD/RP) in vitro, in an attempt to attenuate neuronal damage in ischemic brain vascular diseases. Treatment with DNLA $(0.025-2.5 \mathrm{mg} / \mathrm{mL})$ significantly attenuated neuronal damage, with evidence of increased cell viability, decreased cell apoptosis, and decreased cell morphologic impairment. DNLA have protective effects against OGD/RP-induced neuronal damages in rat primary neuron cultures by stabilizing mitochondrial membrane potential, inhibiting intracellular free calcium overload, and lessening neuron apoptosis mediated by down-regulating mRNA expression of caspase-3 and caspase-12 [59]. Furthermore, DNLA were studied for their protective effects in neuroinflammation as potential mechanism involved in Alzheimer's disease (AD) [16]. AD is characterized by the buildup of two aberrant protein aggregates in the brain, i.e. the amyloid plaques composed of amyloid $\beta$ peptide $(A \beta)$ and neurofibrillary tangles consisted of hyperphosphorylation tau protein [60]. Among a number of pathological abnormalities in $\mathrm{AD}$, inflammatory processes and $A \beta$ deposition trigger neuroinflammatory response, leading to the loss of neurons and the decline of cognitive functions. Thus, $\mathrm{Li}$ et al. (2011) reported inhibitory effects of DNLA on memory impairment induced by liposaccharide (LPS) in rats. Indeed, LPS, an inflammation inducer, has been reported to influence $A \beta$ deposition, and LPS injection to the mouse brain ventricle caused memory deficiency and A $\beta$ accumulation. It was clearly demonstrated, that DNLA treatment $(40,80,160 \mathrm{mg} / \mathrm{kg} / \mathrm{d}$ for 7 days $)$ significantly protected the rat brain from LPS-induced (50 $\mu \mathrm{g})$ neuroinflammation and cognitive dysfunction. This effect appears to be due, at least in part, to suppression of LPS-induced overexpression of hippocampus tumor necrosis factor receptor 1 (TNFR1), possibly through inhibition of phosphorylated p38 mitogen activated protein kinases (p-p38 MAPK) and the downstream NF$\kappa B$ signal pathway [16]. Nie et al. (2016) investigated protective effects of DNLA on A $\beta$ peptide segment 25-35 $\left(\mathrm{A} \beta_{25-35}\right)$-induced neuron and synaptic loss in mice [61]. $10 \mu \mathrm{g}$ of $\mathrm{A} \beta_{25-35}$ was injected into the bilateral ventricles of male mice followed by an oral administration of DNLA (40 mg/kg) for 19 days. The results showed that DNLA significantly attenuated $A \beta_{25-35}$-induced spatial learning and memory impairments in mice. DNLA prevented $A \beta_{25-}$ 35 -induced neuronal loss in the hippocampus and cortex, increased the number of Nissl bodies, improved the ultrastructural injury of neurons and increased the number of synapses in neurons. Consequently, DNLA can prevent neuronal apoptosis and synaptic loss. The neuroprotective 
mechanism may also be associated to the inhibition of hyperphosphorylation of tau protein, which could attenuate the dementia symptoms in AD. Yang et al. (2014) investigated the protective effect of alkaloids enriched extract from $D$. nobile (EDNLA) in LPS-induced hyperphosphorylation of tau protein in rat's hippocampus and LPS-induced apoptosis in rat brain. Rats were administrated intragastrically with different doses of EDNLA (20 and $40 \mathrm{mg} / \mathrm{kg}$ ) every 8 hours for one day, followed by LPS $(100 \mu \mathrm{g})$, injected to the bilateral ventricle. Two hours after injection with LPS, the phosphorylation of tau protein in hippocampus was observed by western blotting. EDNLA groups (20 and 40 $\mathrm{mg} / \mathrm{kg}$ ) obviously decreased the phosphorylation of the tau protein. Additional rats were treated by EDNLA thrice daily for one week, to examine the effects on LPS-induced apoptosis in the brain. EDNLA treatment decreased the number of apoptotic cells around hippocampus in LPStreated groups. EDNLA showed beneficial effects against LPS-induced rat AD model and had anti-apoptosis action in rat's brain [58].

Table 2. Dendrobium spp. and their constituents with neuroprotective activities.

\begin{tabular}{|c|c|c|c|c|}
\hline $\begin{array}{c}\text { Dendrobium species } \\
\text { (organ) }\end{array}$ & Active molecule/type of extract & Biological target & Activity & Refs. \\
\hline $\begin{array}{l}\text { D. auranticum var. } \\
\text { denneanum } \\
\text { (stems) }\end{array}$ & $\begin{array}{l}\text { (-)-(7S,8R,7'E)-4-hydroxy- } \\
3,3^{\prime}, 5,5,5^{\prime} \text {-tetramethoxy-8,4'- } \\
\text { oxyneolign-7'-ene-7,9,9'-triol 7,9'- } \\
\text { bis-O- } \beta \text {-D-glucopyranoside } \\
\text { (-)-syringaresionl-4,4'-bis- } O \text { - } \beta \text {-D- } \\
\text { glucopyranoside }\end{array}$ & $\begin{array}{l}\text { PC12 cells derived from } \\
\text { a pheochromcytoma of the } \\
\text { adrenal medulla }\end{array}$ & $\begin{array}{l}\text { Neuroprotective activity against } \\
\text { glutamate-induced toxicity }\end{array}$ & [66] \\
\hline $\begin{array}{l}\text { D. nobile } \\
\qquad \begin{array}{l}\text { (Not specified) } \\
\text { (stems) }\end{array}\end{array}$ & Alkaloids (DNLA) & $\begin{array}{l}\text { Primary culture of rat cortical } \\
\text { neurons (in vitro) } \\
\text { Rat's hippocampus } \\
\text { Tau protein in rat's } \\
\text { hippocampus } \\
\text { A } \beta_{25-35} \text {-induced spatial } \\
\text { learning and memory } \\
\text { impairments in mice }\end{array}$ & $\begin{array}{l}\text { Attenuation of neuronal damage on } \\
\text { cortical neurons injured by oxygen- } \\
\text { glucose deprivation/reperfusion } \\
\text { Inhibition of LPS-induced memory } \\
\text { impairment } \\
\text { Inhibition of hyperphosphorylation } \\
\text { and LPS-induced apoptosis } \\
\text { Prevention of A } \beta_{25-35-\text { induced }} \\
\text { neuronal and synaptic loss }\end{array}$ & $\begin{array}{l}{[59]} \\
{[16]} \\
{[58]} \\
{[61]}\end{array}$ \\
\hline $\begin{array}{r}\text { D. crepidatum } \\
\text { (stems) }\end{array}$ & $\begin{array}{l}\text { Crepidatol A } \\
\text { Confusarin } \\
\text { 3-(2-acetoxy-5-methoxy)- } \\
\text { phenylpropanol }\end{array}$ & PC12 cells & $\begin{array}{l}\text { Enhancing activity on NGF-induced } \\
\text { neurite outgrowth }\end{array}$ & [65] \\
\hline $\begin{array}{l}\text { D. chrysotoxum } \\
\text { (stems) }\end{array}$ & $\begin{array}{l}\text { Chrisotobibenzyl } \\
\text { Erianin } \\
\text { Chrysotoxine } \\
\text { Chrysotoxine }\end{array}$ & $\begin{array}{l}\mathrm{AChE} \text { and } \mathrm{BChE} \\
\text { Bone marrow neuroblastoma } \\
\text { cells SH-SY5Y }\end{array}$ & $\begin{array}{l}\text { Enzymatic inhibition } \\
\text { Attenuation of 6-OHDA toxicity cells } \\
\text { via mitochondria protection and NF- } \\
\kappa B \text { modulation } \\
\text { Inhibition of the neurotoxicity of 1- } \\
\text { methyl-4-phenyl pyridinium }\left(\mathrm{MPP}^{+}\right) \text {. }\end{array}$ & $\begin{array}{l}62] \\
{[63]} \\
\\
{[64]}\end{array}$ \\
\hline
\end{tabular}

Five bibenzyls and two bibenzyls glucosides were isolated from Dendrobium chrysotoxum to investigate their effect on cholinergic neurotransmission in the central and peripheral nervous systems. Acetylcholine and butyrylcholine esterase (AChE and $\mathrm{BChE}$ ) activity have been used as a marker for cholinergic activity, which plays a crucial role in the learning and memory processes. Indeed, $\mathrm{AChE}$ and $\mathrm{BChE}$ inhibition may slow neurodegeneration in $\mathrm{AD}$ and Parkinson's disease (PD). $\mathrm{AChE}$ and $\mathrm{BChE}$ inhibitory activities of isolated compounds were assayed using a spectrophotometric method. Chrysotobibenzyl, erianin and chrysotoxine had a certain degree of inhibition ratios against $\mathrm{BChE}$ (30.68\%, $41.66 \%$ and $19.35 \%$ of inhibition, respectively) and erianin and chrysotoxine showed weak inhibition ratios against $\mathrm{AChE}$ (14.48\% and 9.87\%, respectively)
[62]. The hypothesis that bibenzyls compounds may be neuroprotective against apoptosis induced by the neurotoxins has been tested. Chrysotobibenzyl, crepidatin, chrysotoxine, moscatilin and nobilin B, isolated from Dendrobium species, were evaluated for their protective effects against 6-hydroxydopamine (6OHDA)-induced toxicity in the human neuroblastoma cell line $\mathrm{SH}-\mathrm{SY} 5 \mathrm{Y}$. 6-OHDA is a reactive oxidative species (ROS) producing agent which generates hydrogen peroxide, superoxide radical a hydroxyl radical involved in PD. This neurotoxin causes selective death of catecholamine-containing neurons. Chrysotoxine showed a significant effect on the attenuation of 6-OHDA-induced apoptosis in SH-SY5Y cells by regulating ROS initiated multiple signaling pathways [63]. The same way, Song et al. (2012) also demonstrated that chrysotoxine inhibits the 
neurotoxicity of 1-methyl-4-phenyl pyridinium $\left(\mathrm{MPP}^{+}\right)$. Inhibition of oxidative stress, mitochondrial dysfunction and imbalance in the multiple cell survival/death signaling pathways were involved in its neuroprotection [64].

To show neuroprotective effects of Dendrobium isolates, the enhancing activity on nerve growth factor (NGF) induced neurite outgrowth in PC12 cells of ten compounds from Dendrobium crepidatum were evaluated in vitro. The results indicated that crepiduatol A, confusarin and 3-(2-acetoxy-5-methoxy)-phenylpropanol enhanced the proportion of the NGF-induced $(10 \mathrm{ng} / \mathrm{mL})$ neurite-bearing cells at a concentration of $10 \mu \mathrm{M}$ [65]. A $8,4^{\prime}$-oxyneolignane glucoside and six other phenolic glucosides from Dendrobium auranticum var. denneanum were assessed for their neuroprotective activity against glutamate-induced toxicity in PC12 cells by an MTT assay. Glutamate induced an inhibition of MTT reduction, while the 8,4'-oxyneolignane glucoside and (-)syringaresinol-4,4'-bis- $O$ - $\beta$-D-glucopyranoside showed neuroprotective activity at a concentration of $10 \mu \mathrm{M}$, with the relative protection of $25.7 \pm 2.2 \%$ and $19.3 \pm 5.6 \%$,

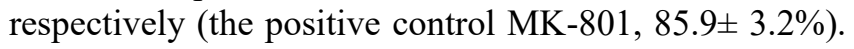
The results indicated that both compounds may be effective in treating neurodegenerative disorders [66].

To assess neuroprotective effects of active substances from Dendrobium herbs, the investigations led during the last decade have been limited to classical molecular targets (Table 2). However, the wealth of molecular information now known about neurodegenerative diseases progression leads to questioning on the efficacy of developed treatments. While Alzheimer targets, for example, the recent discovery that $A \beta$ aggregates at lipid rafts and likely forms neurotoxic pores has led to a new paradigm regarding why past therapeutics may have failed and how to design the next round of compounds for clinical trials [67]. It has been suggested that immunity may contribute to the development of $\mathrm{AD}$ and may itself be targeted in future treatments [68]. Therefore, in light of reported immunostimulating activities detailed below, Dendrobium plants could be promising therapeutic agents in the next decades.

\section{Anti-diabetic properties}

Diabetes mellitus is a chronically metabolic disorder with abnormally high levels of blood glucose (hyperglycemia), which is caused by the deficiency in insulin secretion and/or the decreased response of the organs to insulin. The worldwide incidence of diabetes type 1 and 2 is dramatically increasing in aging population, becoming a global health issue. Available treatments, such as chemically synthetic agents are expensive with some side effects and toxicity. Thus, the investigations for new treatments have been focused on natural compounds with hypoglycemic or anti-glycation activities, $\alpha$-glucosidase inhibitors etc.

Some Dendrobium species have been investigated in such a direction. Suggesting that Dendrobium polysaccharides have the potential to be developed into natural hypoglycemic agents, four polysaccharides from Dendrobium huoshanense, D. officinale, D. nobile and D. chrysotoxum were extracted to compare their hypoglycemic activities in alloxan-induced diabetic mice $(200 \mathrm{mg} / \mathrm{kg}$ b.w.) by oral administration $(200,100$ and 50 $\mathrm{mg} / \mathrm{kg}$ b.w. of Dendrobium polysaccharides). The hypoglycemic activities were based on the serum indices including blood glucose, glycosylated proteins and insulin levels, the changes in pathological morphology of the pancreas. The results indicated that the oral administration of polysaccharides from $D$. huoshanense, $D$. officinale and $D$. nobile, but not D. chrysotoxum, presented significant hypoglycemic activities, at all tested dosages, by the evidence of the decreased levels of fasting blood glucose and glycosylated serum protein as well as the increased level of serum insulin in alloxan-induced diabetic mice. The hypoglycemic effect of the three species could be associated with the successful renovation of injured pancreatic islets, which was reflected not only by the histopathological changes of the pancreas but also by the recovery of decreased insulin release. The observed hypoglycemic effects of four Dendrobium polysaccharides decreased in the order of $D$. huoshanense $>$ D. nobile $>$ D. officinale $>$ D. chrysotoxum [15]. No hypoglycemic effect was found in alloxan-induced mice that were orally administered with $D$. chrysotoxum in spite of the fact that Zhao et al. (2007) previously reported a significant effect on the reduction in blood glucose level by $D$. chrysotoxum polysaccharide (DCP) in the same mice model [18]. The difference between these two hypoglycemic activities of DCP might result from different lavaging dosages, treatment time and extraction procedure of DCP. Indeed, Zhao et al. used DCP at the concentration of $200-500 \mathrm{mg} / \mathrm{kg}$ b.w. on diabetic mice for 7 days, while DCP was orally administered at the concentration of $50-200 \mathrm{mg} / \mathrm{kg}$ b.w. for 12 days by Pan et al. [15]. Evidently, it is necessary to use the same animal model, administered with extracts from the same extraction procedure at the same dosages for the same period to correctly evaluate the capability of different Dendrobium polysaccharides to decrease blood sugar levels.

Four polyphenols from Dendrobium loddigesii, namely loddigesiinols G-J, together with crepiduatol B were evaluated for the $\alpha$-glucosidase inhibitory activity using spectrophotometric method. These five compounds 
showed a strong inhibitory activity with $\mathrm{IC}_{50}$ values from 2.7 to $18.9 \mu \mathrm{M}$, which was significantly stronger than trans-resveratrol used as a positive control $\left(\mathrm{IC}_{50}\right.$ of 27.9 $\mu \mathrm{M})$ [69]. A flavonol glycoside (5-hydroxy-3-methoxyflavone-7- $O$-( $\beta$-D-apiosyl-(1-6))- $\beta$-D-glucoside), as well as gigantol from Dendrobium devonianum were also reported as inhibitors of $\alpha$-glucosidase with the inhibition rate of $43.4 \%$ and $36.7 \%$, respectively [70].

Recently, Xu et al. (2013) presented a theoretical basis for therapy of type- 2 diabetes by searching for potential drug targets in the genome, using gene chip, also called cDNA microarray investigation, which refers to the many specific gene fragments fixed to a solid support [71]. The gene expression profile, as well as blood sugar lowering and lipid-lowering molecular mechanisms of Dendrobium mixtures in diabetic rat model were examined. Three types of Dendrobium mixtures containing Dendrobium officinale together with astragalus, Schisandra, salvia, arrowroot etc. in different proportions were prepared and administrated to diabetic rats over a total period of 48 days. To realize the microarray test, total RNA was extracted from $1 \mathrm{~g}$ of liver tissue. Target genes were mainly related to metabolic processes, cell growth, apoptosis, signal transduction, carbohydrate synthesis, carbohydrate degradation, transcription regulation, olfactory receptors, the microtubule system and the nervous system. The cluster of differentiation (CD) gene family and toll-like receptor9 protein (TLR9) were affected by the treatment of Dendrobium mixtures. TLR9 receptors in diabetic rats had low expression but returned to normal levels after treatment. This indicated that Dendrobium mixtures could improve autoimmune activity in diabetic rats, thereby enhancing the ability of the body to counter external pathogens and stimuli. This study also found a variety of receptors in the $\mathrm{CD}$ gene family with increased levels of expression in the liver of diabetic rats. Overexpression of $\mathrm{CD}$ proteins in diabetic patients provides a fertile environment for tumor growth and differentiation. Dendrobium mixtures therapy not only changed gene expression patterns in type 2 diabetes but also improved immune activity and reduced the likelihood of cancer development. One of the molecular markers of diabetes is Tspan 8 gene. In this study, a three-fold increase of Tspan8 expression was observed in the diabetic rats. Normal expression of Tspan8 was restored after drug treatment, suggesting that this gene could be one of the target sites for Dendrobium mixtures treatment.

Non-enzymatic protein glycation is a complicated reaction process between aldehydic group in reducing sugar and amino group in proteins and ultimately gives the advanced glycation end (AGEs) products, which might alter the structures, functions and stability of peptides and are implicated in diabetic complications, such as diabetic cataract and diabetic artherosclerosis, or even skin disorders, such as delayed wound healing [72]. In vitro anti-glycation activity was assigned to a watersoluble polysaccharide from D. huoshanense (DHP-W2), using a spectrophotometric method, in dose and time dependent manner. DHP-W2 mainly consisted of glucose, xylose, galactose and trace of galacturonic acid, and its average molecular weight was approximately $73 \mathrm{kDa}$. The inhibition of protein glycation by DHP-W2 reached $23 \%$ at the concentration of $0.5 \mathrm{mg} / \mathrm{mL}$ after 3 weeks of reaction as against the same reaction time with vitamin $\mathrm{C}$ at the concentration of $0.3 \mathrm{mg} / \mathrm{mL}$, which inhibited protein glycation by $28 \%$ [73]. Zha et al. (2013) [74] reported that $D$. huoshanense polysaccharide molecular weight decrease, using pectinase hydrolysis, improved its inhibitory action on nonenzymatic glycation of proteins. The sulfation occurred to C-2 and C-6 glucosyl residues seems also to be beneficial to enhance this activity [75]. Diabetic retinopathy (DR) is the most common and serious complication of diabetes. DR leads to the process of vision loss and even blindness, thus the prevention and treatment of DR is a great challenge enhanced by the complexity of this pathogenesis. Angiogenesis plays a major role in the pathogenesis of proliferative DR. Gong et al. (2014) [76] explored the amelioration of ethanol extract of Dendrobium chrysotoxum on streptozotocin (STZ)-induced DR and its engaged mechanisms. The findings showed that $D$. chrysotoxum ethanolic extract can alleviate retinal angiogenesis during the process of DR via inhibiting the expression of vascular endothelial growth factor (VEGF) and VEGF receptor 2 in diabetic rats, and some other pro-angiogenic factors such as MMP 2/9, platelet-derived growth factor $\mathrm{A} / \mathrm{B}$, basic fibroblast growth factor, insulin-like growth factor. Moreover, $D$. chrysotoxum extract can also ameliorate retinal inflammation via inhibiting $\mathrm{NF \kappa B}$ signaling pathway. Decreased retinal mRNA expression of tight junction proteins (including occluding and claudin-1) in diabetic rats was also reversed by $D$. chrysotoxum extract [77]. Concerning Dendrobium isolates, the inhibitory mechanism of erianin has been investigated on retinal neoangiogenesis and its contribution to the amelioration of DR. It has been demonstrated, that erianin inhibits retinal neoangiogenesis by abrogating high-glucoseinduced VEGF expression by blocking ERK1/2 (a subfamily member of MAPKs)-mediated hypoxiainducible factor 1-alpha (HIF-1 $\alpha$ ) activation in retinal endothelial and microglial cells, and further suppressing VEGF-induced activation of VEGFR2 and its downstream signals in retinal endothelial cells [78]. Among other diabetic complications, diabetes-induced cardiomyopathy (DCM) mediated by hyperglycemia can induce the adverse architectural remodeling of heart, and ultimately lead to heart failure and death. Zhang et al. 
(2016) investigated the effects and the possible mechanisms of the Dendrobium officinale extracts (DOE) on diabetic cardiomyopathy in streptozotocin (STZ)induced mice (at the dose of $50 \mathrm{mg} / \mathrm{kg} \mathrm{b.w}$. for 5 consecutive days) [79]. The diabetic mice were received DOE force-feeding once a day for 8 weeks $(75,150$ and $300 \mathrm{mg} / \mathrm{kg}$ ). The results indicated that pretreatment with DOE decreased the heart-to-body weight ratio (HW/BW) and showed an evident hypoglycemic effect. DOE pretreatment significantly decreased creatine kinase, lactate dehydrogenase, total cholesterol and triglyceride levels, limited the production of malonaldialdehyde and increased the activities of superoxide dismutase. The study suggested that DOE possesses the cardioprotective potential against diabetic cardiomyopathy, which may be due to the inhibition of oxidative stress, cardiac lipid accumulation, pro-inflammatory cytokines and cardiac fibrosis. The aim of another in vivo study was to determine the preventive effect of $D$. officinale (DO) on the early complications of STZ-induced diabetic rats [80]. DO (1 $\mathrm{g} / \mathrm{kg} /$ day) was orally administered for 5 weeks, then total cholesterol (TC) and triglyceride (TG), urea nitrogen (BUN), creatinine (CREA) and glutathione peroxidase (GSH-PX) levels were determined, and electroretinographic activity and hypoalgesia were investigated. Treatment with DO significantly attenuated serum levels of TC, TG, BUN and CREA, attenuated the electroretinogram deficits and pathological changes in the eyes of diabetic rats. Moreover, the results indicate that treatment of diabetic rats with DO was effective in improving punctuate mechanical nociception, reduced hypoalgesia and histopathological changes of vital organs induced by hyperglycemia. The protective effect of DO in diabetic rats may be associated with its antioxidant activity, as evidenced by the marked increase in the serum level of GSH-PX. However, DO had no significant effect on blood glucose levels and bodyweight of diabetic rats. In conclusion of this study, DO supplementation is an effective treatment to prevent STZ-induced diabetic complications.

Diabetes mellitus is a chronic disease which a worldwide phenomenon. The cost of diabetes care, both direct and indirect, was $\$ 245$ billion in 2012. Fifty-nine percent of the direct medical cost was for the population aged 65 and over [81]. Therefore, searching for effective anti-diabetic substances is topical and important in order to prevent morbidity in aging population. Dendrobium extracts, polysaccharides and bibenzyls showed promising activities on various anti-diabetic targets (Table 3). However, explored a lead of anti-diabetic ingredients from Dendrobium plants would be more extensive to raise a hope of their development as a treatment.

Table 3. Dendrobium spp. and their constituents with anti-diabetic properties.

\begin{tabular}{|c|c|c|c|c|}
\hline $\begin{array}{c}\text { Dendrobium species } \\
\text { (organ) }\end{array}$ & Active molecule/type of extract & Biological target & Activity & Refs. \\
\hline $\begin{array}{l}\text { D. chrysotoxum } \\
\text { (Not specified) } \\
\text { (stems) }\end{array}$ & $\begin{array}{l}\text { Ethanolic extract } \\
\text { Erianin } \\
\text { Polysaccharide }\end{array}$ & $\begin{array}{l}\text { Diabetic retinopathy } \\
\text { Alloxan-induced diabetic mice }\end{array}$ & $\begin{array}{l}\text { Amelioration of retinal } \\
\text { angiogenesis } \\
\text { Preventing retinal inflammation } \\
\text { and tight junction protein decrease } \\
\text { Inhibition of high-glucose-induced } \\
\text { retinal angiogenesis } \\
\text { Inhibition of the increase in blood } \\
\text { sugar level }\end{array}$ & $\begin{array}{l}76] \\
{[77]} \\
{[78]} \\
{[18]}\end{array}$ \\
\hline $\begin{array}{l}\text { D. devonianum } \\
\quad \text { (whole plant) }\end{array}$ & $\begin{array}{l}\text { 5-hydroxy-3-methoxy-flavone-7- } \\
O \text {-( } \beta \text {-D-apiosyl-(1-6))- } \beta \text {-D- } \\
\text { glucoside } \\
\text { Gigantol }\end{array}$ & $\alpha$-glucosidase in vitro & Enzymatic inhibition & [70] \\
\hline $\begin{array}{r}\text { D. huoshanense } \\
\text { (stems) }\end{array}$ & Polysaccharides & $\begin{array}{l}\text { Alloxan-induced diabetic mice } \\
\text { Protein glycation in vitro }\end{array}$ & $\begin{array}{l}\text { Hypoglycemic } \\
\text { Anti-glycation activity }\end{array}$ & $\begin{array}{l}{[15]} \\
{[73]}\end{array}$ \\
\hline $\begin{array}{r}\text { D. loddigesii } \\
\text { (stems) }\end{array}$ & $\begin{array}{l}\text { Loddigessinol G-J } \\
\text { Crepidatuol B }\end{array}$ & $\alpha$-glucosidase in vitro & Enzymatic inhibition & [69] \\
\hline $\begin{array}{l}\text { D. nobile } \\
\quad \text { (stems) }\end{array}$ & Polysaccharides & Alloxan-induced diabetic mice & Hypoglycemic & [15] \\
\hline $\begin{array}{l}\text { D. officinale } \\
\text { (stems) }\end{array}$ & $\begin{array}{l}\text { Polysaccharides } \\
\text { Mixture with other TCM herbs } \\
\text { Fresh juice } \\
\text { Aqueous extracts (after pre- } \\
\text { extraction with petroleum ether and } \\
80 \% \text { ethanol) }\end{array}$ & $\begin{array}{l}\text { Alloxan-induced diabetic mice } \\
\text { Genome } \\
\text { STZ-induced mice }\end{array}$ & $\begin{array}{l}\text { Hypoglycemic } \\
\text { Gene expression of mechanisms } \\
\text { involved in type } 2 \text { diabetes } \\
\text { Cardioprotective potential against } \\
\text { diabetic cardiomyopathy } \\
\text { STZ-induced diabetic } \\
\text { complications, reduction of } \\
\text { hypoalgesia and histopathological } \\
\text { changes of vital organs induced by } \\
\text { hyperglycemia }\end{array}$ & $\begin{array}{l}{[15]} \\
{[71]} \\
{[79]} \\
{[80]}\end{array}$ \\
\hline
\end{tabular}




\section{Immunomodulatory properties}

Under the effect of aging, immunity becomes slower to respond, autoimmune disorders may develop which can ultimately destroy healthy body tissues [82]. Therefore, action on the immune system in prevention of many agerelated diseases becomes an interesting lead explored by more and more scientists. We are facing a new paradigm that some age-related diseases could be prevented by stimulating the immunity. Polysaccharides are the main effective ingredients of Dendrobium species with the strongest immunomodulatory activities (Table 4). Several studies report diverse investigations of their activities related to immunostimulation or immunoregulation in vitro and in vivo.

The effects of crude polysaccharides from five species of Dendrobium on macrophage function, such as, promoting phagocytosis, release of NO and cytokines IL$1 \alpha$, IL-6, IL-10 and TNF- $\alpha$, were investigated. Polysaccharides from Dendrobium officinale exerted the strongest immunomodulatory activities on mouse macrophage line RAW 264.7 cells [83]. A crude polysaccharide fraction (cDOP) has been determined to be the characteristic marker of $D$. officinale. cDOP was destarched and separated into two subfraction polysaccharides, DOPa and DOPb. Both are composed of mannose and glucose at similar ratios and have similar structure with a backbone of 1,4-linked $\beta$-Dmannopyranosyl and $\beta$-D-glucopyranosyl residues. Significant differences were observed only in their molecular weights. cDOP, DOPa and $\mathrm{DOPb}$ were evaluated on RAW254.7 cell line and showed proliferative activities, as well as enhancing TNF$\alpha$ secretion and phagocytosis in a dose-dependent manner (at the concentrations of 125,250 and $500 \mu \mathrm{g} / \mathrm{mL}$ ). Proliferative effects on lymphocytes alone and with mitogens were also observed. Consequently, DOPa and $\mathrm{DOPb}$ were thus proven to be major active polysaccharide markers of D. officinale [84]. Xia et al. (2012) also partially characterized polysaccharides from the stem of D. officinale; two fractions DOP-1 $(533.7 \mathrm{kDa})$ and DOP$2(159.5 \mathrm{kDa})$ were mainly composed of mannose and glucose with a trace amount of galactose and arabinose [85]. The monosaccharide composition of DOP-1 was mannose:glucose:galactose:arabinose $\quad 3.13: 1.34: 0.02$ : 0.01 , and that of DOP-2 was mannose: glucose:galactose:arabinose 3.13:1.24:0.12:0.02. Both, DOP-1 and DOP-2 were evaluated with in vitro cell models and the data indicated that they exert significant immunomodulatory effects on innate immune responses mediated by spleen lymphocytes, natural-killer (NK) cells and macrophages. DOP-1 exhibited greater effects on lymphocyte activation while DOP-2 was more effective on macrophage activation. D. officinale polysaccharides significantly stimulated the proliferation of splenocytes, DOP-1 was more effective than DOP-2. They also increased NK cell cytotoxicity; it was observed that the optimal polysaccharide concentration was $50 \mu \mathrm{g} / \mathrm{mL}$, which demonstrates that a high concentration is not essential for strong stimulating effects. He et al. (2016) purified a neutral heteropolysaccharide DOP-1-1 from $D$. officinale, which consisted by mannose and glucose (5.8:1) with an average molecular weight of about $1.78 \mathrm{x}$ $10^{5} \mathrm{Da}$ [86]. A partial structure of DOP-1-1 is an $O$ acetylated glucomannan with $\beta$-D-configuration in pyranose sugar forms. Its immunomodulatory activity was evaluated by secretion level of cytokine (IL-1 $\beta$ and IL-10) and TNF- $\alpha$ in vitro. The results showed that DOP1-1 increased significantly the levels of TNF- $\alpha$ and IL- $1 \beta$ in polysaccharide-treated macrophage cells (THP-1) in dose dependent-manner $(25,50$ and $100 \mu \mathrm{g} / \mathrm{mL})$ via the activation of signaling pathways involving ERK1/2 and $\mathrm{NF}-\kappa \mathrm{B}$ (only at the concentration of $25 \mu \mathrm{g} / \mathrm{mL}$ of DOP-11). The aqueous extract (AE) and a purified polysaccharide from the stem of $D$. officinale, Dendronan ${ }^{\circledR}$ (O-acetyl-glucomannan), were examined on RAW 264.7 cells, in order to show whether this is the main component responsible for the immune-stimulating activities. Both, $\mathrm{AE}$ and Dendronan ${ }^{\circledR}$ were shown to be non-cytotoxic (even at a high concentration of 160 $\mu \mathrm{g} / \mathrm{mL}$ ) and can activate macrophages, resulting in enhancing phagocytic activity (Dendronan ${ }^{\circledR}$ at $5-20$ $\mu \mathrm{g} / \mathrm{mL}$ and $\mathrm{AE}$ at $5-40 \mu \mathrm{g} / \mathrm{mL}$ in a dose-dependent manner). Dendronan ${ }^{\circledR}$ at $40 \mu \mathrm{g} / \mathrm{mL}$ and $\mathrm{AE}$ at $80 \mu \mathrm{g} / \mathrm{mL}$ stimulated NO production, and they increased amount of cytokines TNF- $\alpha$, IL- 6 and IL-12 in a dose-dependent manner; Dendronan ${ }^{\circledR}$ showed a significant effect on IL-6 and IL-12 production and a plateau was reached at 80-160 $\mu \mathrm{g} / \mathrm{mL}$. RT-PCR showed that the increases in the secretion of NO, and cytokines are due to the increase in their mRNA expressions. Moreover, Western immunoblotting revealed that Dendronan ${ }^{\circledR}$ was able to upregulate the expression of iNOS protein. The results suggest that Dendronan ${ }^{\circledR}$ is the active component of $D$. officinale [87].

Several studies were also focused on structure and bioactivities of polysaccharides from Dendrobium huoshanense. Zha et al. (2007) investigated a polysaccharide fraction HPS-1B23 obtained from a watersoluble polysaccharide HPS from the stems of $D$. huoshanense [88]. HPS-1B23 consists of glucose, mannose and galactose in the ratio of $31: 10: 8$. The in vitro study showed that HPS-1B23 possessed an enhancing effect on TNF- $\alpha$ production and the peak of $1130.4 \mathrm{pg} / \mathrm{mL}$ was obtained in the culture medium with $200 \mu \mathrm{g} / \mathrm{mL}$. Two types of immune responses are separately regulated by 
cytokines that control two general subsets of helper cells known as Th1 and Th2. IFN- $\gamma$ is evaluated as representative Th1 cytokines mainly secreted from Th1 cells. The highest value of IFN- $\gamma$ was found in splenocyte culture medium treated with $200 \mathrm{mg} / \mathrm{mL}$ of HPS-1B23 in the presence of Concanavalin A (ConA) by the end of culture, which was 3.6-fold that of the blank experiment, suggesting that this polysaccharide has a strong immunostimulating activity. Based on the precedent study, the same research group had an objective to understand the detailed underlying mechanisms of a purified polysaccharide from $D$. huoshanense (DHP). For this purpose, the pattern recognition receptor (PRR) of macrophages RAW264.7 responsible for the recognition of DHP was identified. Results showed that DHP significantly stimulated the secretion of NO, TNF- $\alpha$ and IL-1 $\beta$ in a dose-dependent manner from 10 to $200 \mu \mathrm{g} / \mathrm{mL}$. It was suggested that the plasma membrane of macrophages contains the pattern recognition receptors responsible for recognizing DHP, which further results in the activation of signaling pathways that is relative to the immunostimulatory actions of DHP. This DHP-binding protein was suggested to be Toll Like Receptor 4 (TLR4), the blocking of which may result in the suppression of DHP-induced macrophages activation. After the recognition of corresponding ligand, TLR4 signaling is initiated by its intracellular Toll/interleukin-1 receptor (TIR) domain, which serves as a scaffold for proteinprotein interaction, resulting in a downstream signaling cascade, such as NF- $\mathrm{KB}$, MAPKs and PI3/Akt. In this study, it was found that DHP could activate macrophages through NF- $\kappa B$, MAPKs and PI3 signaling pathways, which is evidenced by not only the changes in the phosphorylation of NF-kB, p38, ERK, JNK and Akt, but also changes in the levels of NO, TNF- $\alpha$ and IL-1 $\beta$ in cells treated with DHP alone or in combination with the specific inhibitors [89]. Hsieh et al. (2008) determined the structure of the active polysaccharide extracted from the mucilage of $D$. huoshanense, which exhibits specific functions in activating murine splenocytes to produce several cytokines including IFN- $\alpha$, IL-10, IL-6, and IL$1 \alpha$, as well as hematopoietic growth factors GM-CSF and G-CSF [90]. A structural modification of stem mucilage polysaccharide by deacetylation of 2-O-glucomannan was investigated whether it would affect its stimulatory effect on cytokine production. Treatment of cells with deacetylated stem mucilage was found to maintain cell proliferation, but fail to induce cytokine production. The active polysaccharide fraction of the mucilage was determined to have an average molecular weight of $\sim 10 \mathrm{kDa}$ for the ratio of glucoside to mannoside $(\sim 1: 10)$ and the degree of acetylation ( $\sim 35 \%)$. A polysaccharide extracted from protocorm-like bodies of $D$. huoshanense,
DHP-4A, with molecular weight of $2.32 \times 10^{5}$ Da was shown to stimulate RAW 264.7 macrophage cells to secrete NO, TNF- $\alpha$, IL-6 and IL-10 via activation of MAPKs (p38, ERK, JNK) and translocation of nuclear $\mathrm{NF}-\kappa \mathrm{B}$, indicating that this polysaccharide also possesses good immunoregulatory activity. DHP-4A consists of glucose, arabinose, mannose and rhamnose with a molar ratio of 13.8:3.0:6.1:2.1 [91]. Lin et al. (2014) showed that D. huoshanense polysaccharides (DH-PS) induced a Th1, Th2, inflammatory cytokines and chemokines in mice in vivo and human in vitro [92]. DH-PS expanded mouse splenocytes in vivo including $\mathrm{CD} 4^{+} \mathrm{T}$ cells, $\mathrm{CD} 8^{+} \mathrm{T}$ cells, B cells, NK cells, NKT cells, monocytes/macrophages, granulocytes and regulatory $\mathrm{T}$ cells. DH-PS induced an anti-inflammatory molecule, IL-1ra, in mouse and human immune cells, especially monocytes. It was observed that IL-1ra level induced by DH-PS was significantly higher than that by $\mathrm{F} 3$, a polysaccharide extract isolated from another popular Chinese herbal medicine, Ganoderma lucidum. D. huoshanense polysaccharides (DHP) also showed immunoregulatory activities in mouse intestine, spleen and liver after oral administration $(50-200 \mathrm{mg} / \mathrm{kg})$, as indicated by the production of cytokines IFN- $\gamma$ and IL4 [93]. Because IFN- $\gamma$ is Th1-associated cytokine and IL4 is Th2-associated cytokine, the different enhancements in the levels of IFN- $\gamma$ and IL-4 secretion caused by DHP in spleen and liver suggested that DHP exerted immunomodulating responses possibly by changing the balance of Th1/Th2.

Extraction methods of polysaccharides may change their chemical properties and so biological activities. Pan et al. (2015) compared immunomodulatory activities of polysaccharides from Dendrobium chrysotoxum (DCP), DCP-H obtained by hot water extraction (HWE) and DCP-E by enzyme-assisted extraction (EAE) [94]. In comparison with DCP-H, DCP-E displayed increased total carbohydrate content as well as the decreased contents of total proteins, while their $\mathrm{Mw}$ showed no significant difference. DCP-E was composed of arabinose, glucose, mannose and galactose with molar ratio of 0.8:85.1:12.7:1.4, while DCP-H was composed of arabinose, glucose, mannose, xylose and galactose with the molar ratio of 1.7:57.5:38.8:0.8:1.5. In combination with ConA, both DCP-E and DCP-H could stimulate splenocyte proliferation of $\mathrm{BALB} / \mathrm{c}$ mice with a dosedependent relationship. DCP-H at the concentrations of 25 and $50 \mu \mathrm{g} / \mathrm{mL}$ provided slightly higher stimulation rate as compared to DCP-E, but there was no significant difference between them ( $p>0.05$ ). At $100 \mu \mathrm{g} / \mathrm{mL}$, DCP$\mathrm{H}$ offered lower stimulation rate, and at $100 \mu \mathrm{g} / \mathrm{mL}$ the stimulation rate of DCP-E was significantly higher $(p<0.05)$ than DCP-H at the same concentration. The results showed a significant difference in immunological 
activity between DCP-E and DCP-H, which may be related to their physicochemical characteristics resulting from different extraction modes.

Investigations focused on polysaccharides from the stems of Dendrobium nobile led to the isolation of a pectic polysaccharide DNP-W5, which was composed of mannose, glucose, galactose, xylose, rhamnose and galacturonic acid in molar ratios of 3.1:8.1:8.2:0.6:4.23.9. $O$-acetyl groups represented approximately $6.9 \%$, but where very important for the expression of the immunological activity of DNP-W5, which displayed remarkable immunoenhancing activities on $\mathrm{T}$ - and $\mathrm{B}-$ lymphocytes [95]. Bioactive tests in vitro also revealed that a rhamnoarabinogalactan DNP-W3 with Mw of 710 $\mathrm{kDa}$ (galactose, rhamnose and arabinose 3.1:1.1:1.0) and an acetylated galactomannoglucan DNP-W2 (glucose, mannose and galactose 6.1:2.9:2.0) isolated from the stems of $D$. nobile could stimulate ConA and LPSinduced $\mathrm{T}$ and B-lymphocyte proliferation and it was thus suggested that both polysaccharides could be potential immunostimulants $[96,97]$.

Several in vivo studies of immunomodulatory activities of Dendrobium polysaccharides were also reported. Different dosages (not precised) of $D$. officinale and its polysaccharides were orally administrated to healthy $\mathrm{BALB} / \mathrm{c}$ mice. After 4 weeks, delayed-type hypersensitivity and natural killer cell activity (cellular immunity), serum hemolytic complement activity (humoral immunity), macrophage phagocytosis (nonspecific immunity) and interferon- $\gamma$ production by splenocytes were measured. The results showed that $D$. officinale and its polysaccharides could significantly enhance cellular immunity and nonspecific immunity in mice. Even if humoral immunity was also enhanced by $D$. officinale, the polysaccharides had no influence after oral administration. The production of interferon- $\gamma$ by murine splenocytes was markedly increased. The molecular weight of the major fraction from the polysaccharides was $533 \mathrm{Da}$, and was composed of mannose, glucose and rhamnose in a molar ratio of 7.3:1.3:1.0 [98]. Because the immunomodulating effects of $D$. officinale polysaccharides were individually evaluated using in vitro splenic cell or macrophage model after the isolation and purification of single fraction, it is uncertain whether or not they are the most effective fractions in total polysaccharide extracts of $D$. officinale. The aim of the study of Xie et al. (2016) was to identify homogenous polysaccharide fractions with high intestinal immunomodulating activity from $D$. officinale stems [99]. DOP-W3-b was thus obtained through a bioactivityguided sequential isolation procedure based on in vitro Peyer's patch-mediated immunomodulating activity assay. Peyer's patches are composed of follicle-associated epithelium containing specialized epithelial cells $-\mathrm{M}$ cells and highly specialized lymphoid follicles containing numerous B-cells, T-cells, dendritic cells and macrophages, and have been reported to be essential inductive sites for initiating the intestinal mucosal immune response. Aqueous solutions of DOP-W3-b were orally administered to mice once per day for 3 or 7 days, $500 \mathrm{mg} / \mathrm{kg}$ b.w. and $2 \mathrm{~g} / \mathrm{kg}$ b.w. DOP-W3-b time- and dose-dependently stimulated the proliferation of bone marrow cells by the oral administration of $0.5 \mathrm{~g} / \mathrm{kg}$ or $2 \mathrm{~g} / \mathrm{kg}$ for consecutive seven days. Compared to the control (distilled water administration), the proliferation of bone marrow cells by Peyer's patch cell supernatant was increased by $19.8 \%$ on the third day and $34.2 \%$ on the seventh day with $0.5 \mathrm{~g} / \mathrm{kg} /$ day oral administration, and by $35.2 \%$ on the third day and $71.7 \%$ on the seventh day with $2 \mathrm{~g} / \mathrm{kg}$ per day oral administration, suggesting that DOPW3-b is a potent modulator for the production of hematopoietic growth factor. Structure analysis indicated that DOP-W3-b was composed of mannose and glucose in a molar ratio of 4.5 with a relatively low molecular weight of $1.543 \times 10^{4} \mathrm{Da}$. The immunomodulatory activities of Dendronan ${ }^{\circledR}$ in vivo in relation to cell mediated and humoral immunity was investigated using a long-term immunosuppressed mice model. The overall results proved that Dendronan ${ }^{\circledR}$ significantly promoted the splenocyte proliferation (at $80 \mathrm{mg} / \mathrm{kg} \mathrm{BW}$ ), corrected the imbalance in spleen lymphocytes subsets ratio (CD3 ratio at $40 \mathrm{mg} / \mathrm{kg} \mathrm{BW}$ ), reversed the diminution of cytokine levels (TNF- $\alpha$ secretion at $80 \mathrm{mg} / \mathrm{kg} \mathrm{BW}$ ), and stimulated the formation of Ig and heamolysin $(40 \mathrm{mg} / \mathrm{kg}$ BW) [100].

Water-soluble polysaccharide was isolated from the stem of Dendrobium tosaense (DTP). Fractioning of DTP produced a neutral polysaccharide fraction DTP-N (87\%). DTP and DTP-N consisted of galactose, glucose, and mannose in ratios of $1: 9.1: 150.7$ and 1:12.2:262.5, respectively. DTP-N represents the major portion of DTP, which might explain why the Mw of DTP and DTP-N were similar to each other, with an average Mw of 305 $\mathrm{kDa}$ and $221 \mathrm{kDa}$, respectively. Immunomodulatory effects of DTP administered orally to Balb/c mice for 3 weeks were investigated and it was concluded oral administration of $100 \mathrm{mg} / \mathrm{kg}$ and $300 \mathrm{mg} / \mathrm{kg}$ of DTP led to a $16.9 \%$ and $18.2 \%$ increase in the population of splenic NK cells compared with the control group. Moreover, splenocyte proliferation was substantially enhanced by LPS stimulation in a dose-dependent manner in both DTP-treated groups $(100$ and $300 \mathrm{mg} / \mathrm{kg})$ and the same DTP treatments significantly up regulated the proliferation of splenocytes through ConA stimulation, compared with the control group. However, DTP exerted no effects on the population of T cells, B cells, cytotoxic $\mathrm{T}$ cells, or helper T cells [101]. 
Table 4. Dendrobium spp. and their constituents with immunomodulatory activities

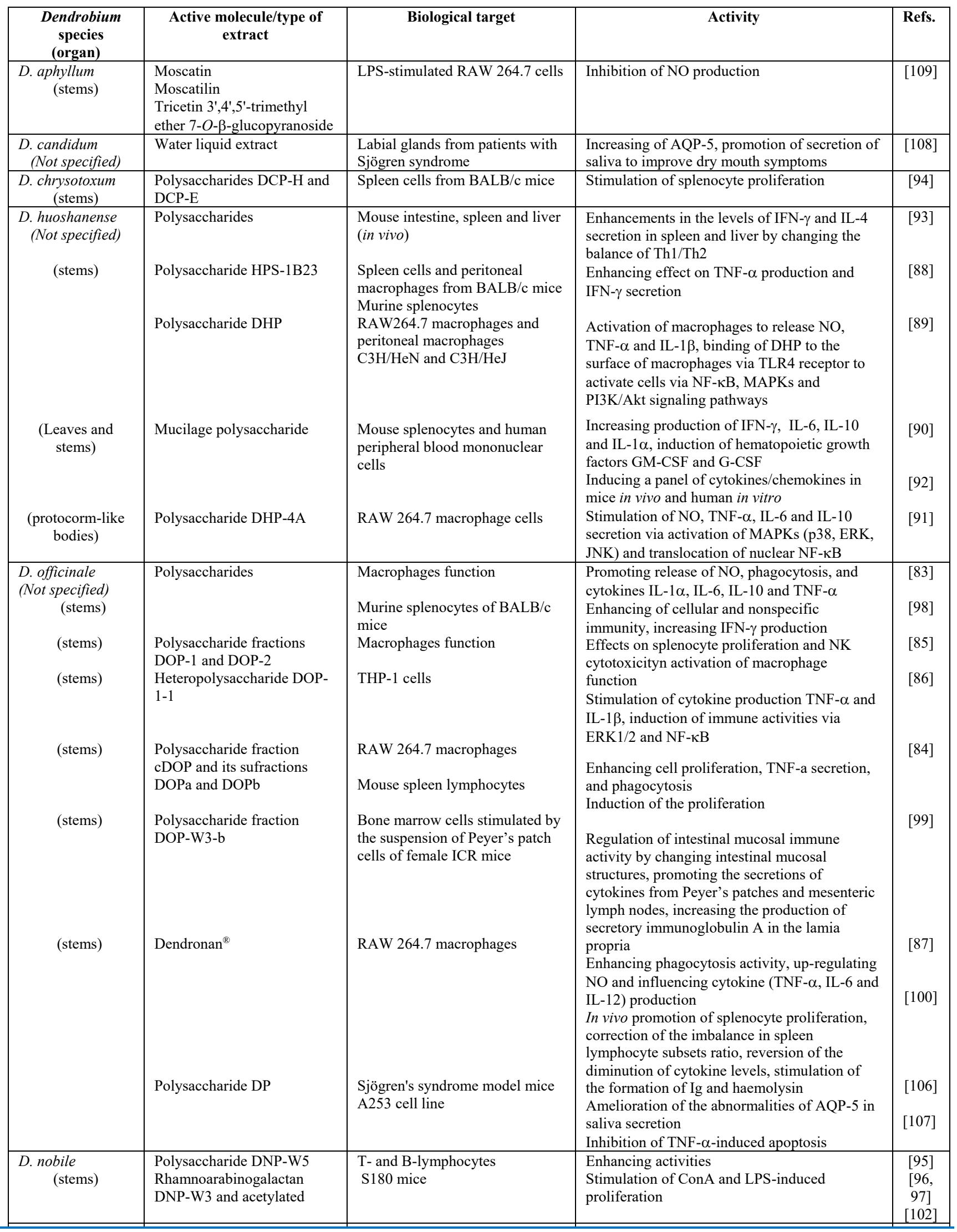




\begin{tabular}{|c|l|l|l|l|}
\hline & $\begin{array}{l}\text { galactomannoglucan DNP- } \\
\text { W2 } \\
\text { Polysaccharide DNP4-2 }\end{array}$ & $\begin{array}{l}\text { Increasing of immune index and promotion of } \\
\text { cytokine secretion in vivo }\end{array}$ & \\
\hline $\begin{array}{c}\text { D. tosaense } \\
\text { (stems) }\end{array}$ & Polysaccharide DTP & $\begin{array}{l}\text { Splenic NK cells, splenocytes in } \\
\text { BALB/c mice }\end{array}$ & $\begin{array}{l}\text { Stimulation of the population of splenic NK } \\
\text { cells, cytotoxicity, macrophage phagocytosis, } \\
\text { and cytokine induction }\end{array}$ & \begin{tabular}{c} 
[101] \\
\hline
\end{tabular} \\
\hline
\end{tabular}

Four polysaccharide fractions from D. nobile, DNP1-1, DNP2-1, DNP3-1, and DNP4-2, were evaluated for their immunomodulation effects. Mice were injected intraperitoneally once a day over 10 days with $5,2.5$ and $1.25 \mathrm{mg} / \mathrm{mL}$ of each polysaccharide. To evaluate the effect of the polysaccharide fractions on the immune system, the spleen and thymus index (weight of spleen/thymus (mg)/body weight (g)) were calculated. All the polysaccharide-treatment groups except DNP4-2 exhibited a lower value of spleen index, which indicates that there was no significant increasing effect of the three polysaccharides on the spleen index in the mice. At the dose of $2.5 \mathrm{mg} / \mathrm{mL}$ of DNP4-2, significant increasing was observed, but not in a concentration-dependent manner. All polysaccharide fractions exhibited strong increasing effects on the thymus index, especially for DNP4-2 at the concentration of $2.5 \mathrm{mg} / \mathrm{mL}$, but not in a concentrationdependent manner. Moreover, at this dose, DNP4-2 strongly promoted the secretion of cytokines TNF- $\alpha$, IFN$\gamma$ and IL-2 [102].

Immunomodulatory effects of orally administrated crude polysaccharide fraction of $D$. huoshanense was clinically evaluated on patients with moderate to severe recalcitrant atopic dermatitis (AD). The cause of $A D$ is unknown but believed to involve among others immune system dysfunction. The condition typically starts in childhood with changing severity over the years [103]. Twenty-seven patients aged from 4-18 years that had not responded to topical therapy were treated with polysaccharides from $D$. huoshanense for 4 weeks and followed-up for another 4 weeks. Serum levels of IL-5, IL-13, IFN- $\gamma$, and TGF- $\beta 1$ decreased significantly between weeks 0 and 4 and between weeks 0 and 8 . No significant difference in the levels of IL-10 was found. The polysaccharide from $D$. huoshanense reduced the levels of some cytokines associated with atopic dermatitis and had beneficial effects on symptoms. No serious adverse effects occurred when it was administered orally for 4 weeks [104].

Sjögren's syndrome (SS) is a chronic autoimmune disease with exocrine glands disorder with associated lymphocytes infiltration, and is usually clinically manifested as dry eyes and dry mouth [105]. In SS patients, an over-expression of TNF- $\alpha$, IL- $1 \beta$ and IL- 6 is observed in response to immune-mediated inflammation, as well as an abnormality of aquaporin 5 (AQP-5) in saliva secretion. Dendrobium officinale polysaccharide (DP) and its possible protective effect on the submandibular gland from the progressive destruction in the experimental SS model mice was examined by Lin et al. (2011) [106]. DP was found to consist of mannose, glucose, galactose, arabinose, xylose and glucuronic acid in the molar ratio of $10: 0.25: 1.2: 4.7: 1.3: 1.4$. Mice were administrated with $200 \mu \mathrm{L}$ of DP at the dose of $20 \mathrm{mg} / \mathrm{mL}$ in physiological saline per day for 25 days. The proinflammatory cytokines TNF- $\alpha$, IL- 6 , IL- $1 \beta$ and its activator MMP-9, were found over-expressed in the model mice, but significantly suppressed by the treatment of DP. Given that the AQP-5 is suppressed by the TNF- $\alpha$ in the murine lung epithelial cells, it was speculated that the decrease of AQP-5 in the model mice is, at least partially, due to the up-regulated expression of TNF- $\alpha$. The inhibition of AQP-5 was directly assessed by the addition of human TNF- $\alpha$ on A253 human salivary cell line. Significantly decreased AQP-5 protein levels were observed after treatment with TNF- $\alpha 100$ units $/ \mathrm{mL}$ for $8 \mathrm{hr}$, but was reversed by the pre-treatment of DP in a dose-dependent manner. However, even though the DP administration ameliorated the expression of AQP-5 in SG, there was still a fair decrease in the DP group compared with the control group. The results indicated that there might be other factors responsible for the decrease of AQP-5. Furthermore, the protective effect of DP on A253 cell line against TNF- $\alpha$-induced apoptosis was investigated by Xing et al. 2013 [107]. A253 cells were pre-treated with DP for $12 \mathrm{hr}$ before TNF- $\alpha$ addition, then NF- $\kappa$ B, phosphorylation of MAPKs, ROS generation, mitochondrial membrane potential and proapoptotic proteins were examined. In summary, prolonged MAPK activation and translocation of $\mathrm{p} 65$ subunit of NF- $\kappa$ B in the nuclei were observed, as well as decreased mitochondrial membrane potential and accumulated cellular ROS, leading to the dramatic upregulation of apoptotic proteins. Pre-treatment with DP was further demonstrated to be protective in a dosedependent manner in response to the TNF- $\alpha$ stimulus. In research for potential therapies, sixteen patients with SS suffered from deficient secretion of saliva due to an autoimmune destruction of salivary glands leading to dry mouth symptoms, were orally administered with Dendrobium candidum extracted liquid (DCEL) for 1 week. Saliva and salivary glands biopsies from labial glands of patients were collected and examined by immunoreactivity and immunohistochemistry techniques. Results showed that salivary secretion increased by about 
$65 \%$ in patients treated with DCEL as compared with the control group. It was demonstrated that $D$. candidum extract would regulate the expression of AQP-5 in labial glands of SS patients and thereby promoted secretion of saliva to improve dry mouth symptoms [108].

Besides polysaccharides, phenolic compounds from Dendrobium aphyllum, namely moscatin, moscatilin and tricetin 3',4',5'-trimethyl ether 7-O- $\beta$-glucopyranoside, inhibited NO production at the concentration of $25 \mu \mathrm{M}$ in LPS-stimulated RAW 264.7 cells with the inhibition of $32.48 \%, 35.68 \%$ and $38.50 \%$, respectively [109].<smiles>COc1cc(CC(C2=C(O)C(=O)c3cc(O)c4cc(O)ccc4c3C2=O)c2cc(O)c(O)c(OC)c2)ccc1O</smiles><smiles>COc1cc(CC(C2=C(O)C(=O)c3ccc4cc(O)ccc4c3C2=O)c2cc(OC)c(O)c(OC)c2)ccc1O</smiles><smiles>COc1cc([C@H]2c3cc(O)c4ccc5cc(O)ccc5c4c3O[C@H]2c2cc(OC)c(O)c(OC)c2)ccc1O</smiles><smiles>COc1cc([C@@H]2Oc3cc(O)c4c(c3CCc3cc(O)ccc3-4)[C@H]2c2cc(OC)c(O)c(OC)c2)ccc1O</smiles>

Loddigesiinol I Loddigesiinol J<smiles>C=C(CC)[C@H]1Oc2cc(OC)cc(CCc3ccc(O)c(OC)c3)c2C[C@H]1C</smiles>

Figure 2. Chemical structures of anti-diabetic compounds of loddigesiinols G-K from $D$. loddigesi.

\section{Patents}

In light of above mentioned scientific papers focused on Dendrobium extracts and isolates and their activities associated to aging-related diseases, the existence of patents seems obvious. Since 2005, more than 320 patents have been registered, mostly Chinese, dealing with preparations containing Dendrobium plants for conditioning, regulating or alleviating cancer, diabetes or improve human immunity. However, if we look at these inventions closely, we become aware that the majority of them focus on Traditional Chinese medicine prescriptions associated to at least about ten other Chinese herbs, such as Ganoderma lucidum, ginseng, licorice, astragalus, Millettia speciosa etc., to produce synergism and enhance targeted health benefits (patents CN105441280, 
CN103566350, CN105748996, CN105494776). The inventions describe various beverages (teas, wines), food, powders, gels, capsules and production methods thereof. The prescriptions are mostly preventive or assisting diabetes treatments, reducing blood glucose, improving yin-deficiency, and accompanying patients with chemotherapy or radiotherapy. Furthermore, the majority of the patented preparations mention only Dendrobium, dendrobe or herba dendrobii without precision of the species; some of them contain other orchids included in Chinese Pharmacopoeia, such as Gastrodia elata or Bletilla striata (patents CN105902844, CN105597027). If we focus on specific Dendrobium species, D. officinale takes part of an instant powder or healthy liquor enhancing immunity and improving the anti-cancer effect of this species (patents CN105533744, CN105602812). D. officinale root extract is also exploited in for controlling high blood sugar and improving sugar tolerance (patent CN105434886). Dendrobium candidum preparation with walnut kernels, asparagus roots, Codonopsis pilosula, Chinese angelica, Ligusticum wallichii and licorice has a synergic effect and can significantly improve body discomfort caused by tumor pain and adverse effects arising from antitumour treatment, particularly lung cancer patients (patent CN104606510). A traditional Chinese medicine containing 29 ingredients of which Dendrobium nobile, has been registered to effectively treat diabetes (patent CN105596776). Only few patents deal with Dendrobium phytochemicals. Dendrophenol (syn. moscatilin) has been patented as an agent inhibiting cervical cancer cell proliferation and inducing autophagic apoptosis in vitro in an effective concentration in the range of $25-200 \mathrm{~mol} / \mathrm{L}$ (patent CN105943523). Loddigesiinols G-K (Fig. 2) have been registered to be used as hypoglycemic drug for preventing and curing cardiovascular disease (patent CN103664568).

\section{Conclusion}

In this review, we reported the main research on Dendrobium species and their most active constituents. Searching for anticancer properties of Dendrobium plants, various targets and mechanisms have been explored. Whereas anticancer mechanisms of gigantol, moscatilin, denbinobin or erianin have been explored, there are still many studies, which are satisfied with the evaluation of cytotoxicity against cancer cell lines and miss in depth explorations. To the best of our knowledge, no Dendrobium anticancer drug has been subjected to clinical trials. Several species of Dendrobium exerted neuroprotective activities, but their evaluation on modern targets should be undertaken in the future. Their immunomodulatory activities are promising and interesting clinical studies on patients with Sjögren syndrome or atopic dermatitis have been reported [104, 108]. In light of recent discoveries about the connections between immunity and diseases developed in the elderly, this lead would continue to be explored and more clinical studies would be realized to confirm in vitro and in vivo investigations. Dendrobium species also showed interesting hits on anti-diabetic targets, but they seem to be more useful against diabetic complications, such as diabetic retinopathy. The existence of several patents has also been mentioned in this review, which is an unusual, but pertinent issue. Even if the majority of the patents are related to mixtures of TCM herbs, including Dendrobium, a will of a potential development of acquired knowledge has to be noticed. Whatever happens, given the investigations of Dendrobium herbs and their constituents, which have been led during the last decade, an untapped potential for the development of new therapeutic agents for treating age-related pathologies is undeniable.

\section{Acknowledgements}

The authors sincerely thank Grahame Mowatt for carefully reading and correcting the manuscript.

\section{References}

[1] Lam Y, Ng TB, Yao RM, Shi J, Xu K, Sze SC, et al. (2015). Evaluation of chemical constituents and important mechanism of pharmacological biology in Dendrobium plants. Evid-based Compl Alt, 2015: 841752

[2] Xu J, Han QB, Li SL, Chen XJ, Wang XN, Zhao ZZ, et al. (2013). Chemistry, bioactivity and quality control of Dendrobium, a commonly used tonic herb in traditional Chinese medicine. Phytochem Rev, 12: 341-367

[3] Ng TB, Liu J, Wong JH, Ye X, Wing Sze SC, Tong Y, et al. (2012). Review of research on Dendrobium, a prized folk medicine. Appl Microbiol Biotechnol, 93: 1795-1803

[4] da Silva JA, Cardoso JC, Dobranszki J, Zeng S (2015). Dendrobium micropropagation: a review. Plant Cell Rep, 34: 671-704

[5] Lin Y, Wang F, Yang LJ, Chun Z, Bao JK, Zhang GL (2013). Anti-inflammatory phenanthrene derivatives from stems of Dendrobium denneanum. Phytochemistry, 95: 242-251

[6] Hu JM, Chen JJ, Yu H, Zhao YX, Zhou J (2008). Five new compounds from Dendrobium longicornu. Planta Med, 74: 535-539

[7] Tian CC, Zha XQ, Luo JP (2015). A polysaccharide from Dendrobium huoshanense prevents hepatic inflammatory response caused by carbon tetrachloride. Biotechnol Equip, 29: 132-138 
[8] Pan LH, Lu J, Luo JP, Zha XQ, Wang JH (2012). Preventive effect of a galactoglucomannan (GGM) from Dendrobium huoshanense on selenium-induced liver injury and fibrosis in rats. Exp Toxicol Pathol, 64: 899-904

[9] Sukphan P, Sritularak B, Mekboonsonglarp W, Lipipun V, Likhitwitayawuid K (2014). Chemical constituents of Dendrobium venustum and their antimalarial and anti-herpetic properties. Nat Prod Comm, 9: 825-827

[10] Sattayasai N, Sudmoon R, Nuchadomrong S, Chaveerach A, Kuehnle AR, Mudalige-Jayawickrama RG, et al. (2009). Dendrobium findleyanum agglutinin: Production, localization, anti-fungal activity and gene characterization. Plant Cell Rep, 28: 1243-1252

[11] Xing YM, Chen J, Cui JL, Chen XM, Guo SX (2011). Antimicrobial activity and biodiversity of endophytic fungi in Dendrobium devonianum and Dendrobium thyrsiflorum from Vietman. Curr Microbiol, 62: 12181224

[12] Luo A, Fan Y (2011). In vitro antioxidant of a watersoluble polysaccharide from Dendrobium fimbriatum Hook.var.oculatum Hook. Int J Mol Sci, 12: 4068 4079

[13] Luo A, Ge Z, Fan Y, Luo A, Chun Z, He X (2011). In vitro and in vivo antioxidant activity of a water-soluble polysaccharide from Dendrobium denneanum. Molecules, 16: 1579-1592

[14] Lo SF, Nalawade SM, Mulabagal V, Matthew S, Chen CL, Kuo CL, et al. (2004). In vitro propagation by asymbiotic seed germination and 1,1-diphenyl-2picrylhydrazyl (DPPH) radical scavenging activity studies of tissue culture raised plants of three medicinally important species of Dendrobium. Biol Pharm Bull, 27: 731-735

[15] Pan LH, Li XF, Wang MN, Zha XQ, Yang XF, Liu ZJ, et al. (2014). Comparison of hypoglycemic and antioxidative effects of polysaccharides from four different Dendrobium species. Int J Biol Macromol, 64: 420-427

[16] Li Y, Li F, Gong Q, Wu Q, Shi J (2011). Inhibitory effects of Dendrobium alkaloids on memory impairment induced by lipopolysaccharide in rats. Planta Med, 77: 117-121

[17] Sun J, Guo Y, Fu X, Wang Y, Liu Y, Huo B, et al. (2016). Dendrobium candidum inhibits MCF-7 cells proliferation by inducing cell cycle arrest at G2/M phase and regulating key biomarkers. Oncotargets Ther, 9: 21-30

[18] Zhao Y, Son YO, Kim SS, Jang YS, Lee JC (2007). Antioxidant and anti-hyperglycemic activity of polysaccharide isolated from Dendrobium chrysotoxum Lindl. J Biochem Mol Biol, 40: 670-677

[19] Kovacs A, Vasas A, Hohmann J (2008). Natural phenanthrenes and their biological activity. Phytochemistry, 69: 1084-1110

[20] Dillin A, Gottschling DE, Nystrom T (2014). The good and the bad of being connected: the integrons of aging. Curr Opin Cell Biol, 26: 107-112
Vallejo NA (2012). Aging Successfully: a Research and Public Health Priority for the 21st Century. Aging Dis, 3: 1-4

Vallejo NA (2011). Immune aging and challenges for immune protection of the graying population. Aging Dis, 2: 339-345

Zhao X, Sun P, Qian Y, Suo H (2014). D. candidum has in vitro anticancer effects in HCT-116 cancer cells and exerts in vivo anti-metastatic effects in mice. Nutr Res Pract, 8: 487-493

Prasad R, Koch B (2014). Antitumor activity of ethanolic extract of Dendrobium formosum in T-cell lymphoma: an in vitro and in vivo study. Biomed Res Int, 2014: 753451

Moretti M, Cossignani L, Messina F, Dominici L, Villarini M, Curini M, et al. (2013). Antigenotoxic effect, composition and antioxidant activity of Dendrobium speciosum. Food Chem, 140: 660-665

Zheng Q, Qiu D, Liu X, Zhang L, Cai S, Zhang X (2015). Antiproliferative effect of Dendrobium catenatum Lindley polypeptides against human liver, gastric and breast cancer cell lines. Food Funct, 6: 1489-1495

Chen XJ, Mei WL, Cai CH, Guo ZK, Song XQ, Dai HF (2014). Four new bibenzyl derivatives from Dendrobium sinense. Phytochem Lett, 9: 107-112

Chaotham C, Pongrakhananon V, Sritularak B, Chanvorachote P (2014). A bibenzyl from Dendrobium ellipsophyllum inhibits epithelial-tomesenchymal transition and sensitizes lung cancer cells to anoikis. Anticancer Res, 34: 1931-1938

Chaotham C, Chanvorachote P (2015). A bibenzyl from Dendrobium ellipsophyllum inhibits migration in lung cancer cells. J Nat Med, 69(4): 565-74

$\mathrm{Xu}$ FQ, Xu FC, Hou B, et al. (2014). Cytotoxic bibenzyl dimers from the stems of Dendrobium fimbriatum Hook. Bioorg Med Chem Lett, 24: 52685273

Klongkumnuankarn P, Jongbunprasert V, Busaranon K, Chanvorachote P, Sritularak B, Likhitwitayawuid K (2015). Cytotoxic and Antimigratory Activities of Phenolic Compounds from Dendrobium brymerianum. Evidbased Compl Alt, 2015: 350410

Kowitdamrong A, Chanvorachote P, Sritularak B, Pongrakhananon V (2013). Moscatilin inhibits lung cancer cell motility and invasion via suppression of endogenous reactive oxygen species. Biomed Res Int: 765894

Chanvorachote P, Kowitdamrong A, Ruanghirun T, Sritularak B, Mungmee C, Likhitwitayawuid K (2013). Anti-metastatic activities of bibenzyls from Dendrobium pulchellum. Nat Prod Comm, 8: 115-118 Tsai AC, Pan SL, Liao CH, et al. (2010). Moscatilin, a bibenzyl derivative from the India orchid Dendrobrium loddigesii, suppresses tumor angiogenesis and growth in vitro and in vivo. Cancer Lett, 292: 163-170

Chen TH, Pan SL, Guh JH, et al. (2008). Moscatilin Induces apoptosis in human colorectal cancer cells: a crucial role of c-Jun NH2-terminal protein kinase 
activation caused by tubulin depolymerization and dna damage. Clin Cancer Res, 14: 4250-4258

[36] Chen CA, Chen CC, Shen CC, Chang HH, Chen YJ (2013). Moscatilin induces apoptosis and mitotic catastrophe in human esophageal cancer cells. J Med Food, 16: 869-877

[37] Charoenrungruang S, Chanvorachote P, Sritularak B, Pongrakhananon V (2014). Gigantol, a Bibenzyl from Dendrobium draconis, inhibits the migratory behavior of non-small cell lung cancer cells. J Nat Prod, 77: 1359-1366

[38] Charoenrungruang S, Chanvorachote P, Sritularak B, Pongrakhananon V (2014). Gigantol-induced apoptosis in lung cancer cell through mitochondrialdependent pathway. Thai J Pharm Sci, 38: 67-73

[39] Unahabhokha T, Chanvorachote P, Pongrakhananon $\mathrm{V}$ (2016). The attenuation of epithelial to mesenchymal transition and induction of anoikis by gigantol in human lung cancer H460 cells. Tumour Biol 37: 8633-8641

[40] Unahabhokha T, Chanvorachote P, Sritularak B, Kitsongsermthon J, Pongrakhananon V (2016). Gigantol inhibits epithelial to mesenchymal process in human lung cancer cells. Evid-based Compl Alt, 2016: 4561674

[41] Sun J, Fu X, Wang Y, Liu Y, Zhang Y, Hao T, et al. (2016). Erianin inhibits the proliferation of T47D cells by inhibiting cell cycles, inducing apoptosis and suppressing migration. Am J Transl Res, 8: 3077-3086

[42] Wang H, Zhang T, Sun W, Wang Z, Zuo D, Zhou Z, et al. (2016). Erianin induces G2/M-phase arrest, apoptosis, and autophagy via the ROS/JNK signaling pathway in human osteosarcoma cells in vitro and in vivo. Cell Death Dis, 7: e2247

[43] Pengpaeng P, Sritularak B, Chanvorachote P (2015). Dendrofalconerol A sensitizes anoikis and inhibits migration in lung cancer cells. J Nat Med, 69: 178-190

[44] Pengpaeng P, Sritularak B, Chanvorachote P (2015). Dendrofalconerol A suppresses migrating cancer cells via EMT and integrin proteins. Anticancer Res, 35: 201-205

[45] Huang YC, Guh JH, Teng CM (2005). Denbinobinmediated anticancer effect in human K562 leukemia cells: role in tubulin polymerization and Bcr-Abl activity. J Biomed Sci , 12: 113-121

[46] Sanchez-Duffhues G, Calzado MA, Garcia de Vinuesa A, Appendino G, Fiebich BL, Loock U, et al. (2009). Denbinobin inhibits nuclear factor- $\kappa \mathrm{B}$ and induces apoptosis via reactive oxygen species generation in human leukemic cells. BiochemPharmacol, 77: 14011409

[47] Song JI, Kang YJ, Yong HY, Kim YC, Moon A (2012). Denbinobin, a phenanthrene from Dendrobium nobile, inhibits invasion and induces apoptosis in SNU-484 human gastric cancer cells. Oncol Rep, 27: 813-818

[48] Weng HY, Hsu MJ, Chen CC, Chen BC, Hong CY, Teng CM, et al. (2013). Denbinobin induces human glioblastoma multiforme cell apoptosis through the
IKK $\alpha$-Akt-FKHR signaling cascade. Eur J Pharmacol, 698: 103-109

[49] Lu TL, Han CK, Chang YS, Lu TJ, Huang HC, Bao BY, et al. (2014). Denbinobin, a phenanthrene from Dendrobium nobile, impairs prostate cancer migration by inhibiting rac1 activity. Am J Chin Med, 42: 15391554

[50] Hsu JL, Lee YJ, Leu WJ, et al. (2014). Moniliformediquinone induces in vitro and in vivo antitumor activity through glutathione involved dna damage response and mitochondrial stress in human hormone refractory prostate cancer. J Urol, 191: 14291438

[51] Mittraphab A, Muangnoi C, Likhitwitayawuid K, Rojsitthisak P, Sritularak B (2016). A new Bibenzylphenanthrene derivative from dendrobium signatum and its cytotoxic activity. Nat Prod Comm, 11: 657659

[52] Zhou XM, Zheng CJ, Gan LS, Chen GY, Zhang XP, Song XP, et al. (2016). Bioactive Phenanthrene and Bibenzyl Derivatives from the Stems of Dendrobium nobile. J Nat Prod, 79: 1791-1797

[53] Zhou XM, Zheng CJ, Wu JT, Chen GY, Chen J, Sun CG (2016). Five new lactone derivatives from the stems of Dendrobium nobile. Fitoterapia, 115: 96-100 Li G, Sun P, Zhou Y, Zhao XIN, Chen F (2014). Preventive effects of Dendrobium candidum Wall ex Lindl. on the formation of lung metastases in BALB/c mice injected with 26-M3.1 colon carcinoma cells. Oncology Lett, 8: 1879-1885

[55] Wang Q, Sun P, Li G, Zhu K, Wang C, Zhao X (2014). Inhibitory effects of Dendrobium candidum Wall ex Lindl. on azoxymethane- and dextran sulfate sodiuminduced colon carcinogenesis in C57BL/6 mice. Oncology Lett, 7: 493-498

[56] Zhao Y, Liu Y, Lan XM, Xu GL, Sun YZ, Li F, et al. (2016). Effect of Dendrobium officinale Extraction on Gastric Carcinogenesis in Rats. Evid-based Compl Alt, 2016: 1213090

[57] Pai HC, Chang LH, Peng CY, Chang YL, Chen CC, Shen CC, et al. (2013). Moscatilin inhibits migration and metastasis of human breast cancer MDA-MB-231 cells through inhibition of Akt and Twist signaling pathway. J Mol Med, 91: 347-356

[58] Yang S, Gong Q, Wu Q, Li F, Lu Y, Shi J (2014). Alkaloids enriched extract from Dendrobium nobile Lindl. attenuates tau protein hyperphosphorylation and apoptosis induced by lipopolysaccharide in rat brain. Phytomedicine, 21: 712-716

[59] Wang Q, Gong Q, Wu Q, Shi J (2010). Neuroprotective effects of Dendrobium alkaloids on rat cortical neurons injured by oxygen-glucose deprivation and reperfusion. Phytomedicine, 17: 108115

[60] Selkoe DJ (2001). Alzheimer's disease: genes, proteins, and therapy. Physiol rev, 81: 741-766

Nie J, Tian Y, Zhang Y, Lu YL, Li LS, Shi JS (2016). Dendrobium alkaloids prevent Abeta25-35-induced neuronal and synaptic loss via promoting neurotrophic factors expression in mice. PeerJ, 4: e2739 
[62] Dong FW, Luo HR, Wan QL, Xu FQ, Fan WW, Wang KJ, et al. (2012). Two New Bibenzyl Glucosides from Dendrobium chrysotoxum. Bull Korean Chem Soc, 33: 2247-2250

[63] Song JX, Shaw PC, Sze CW, Tong Y, Yao XS, Ng TB, et al. (2010). Chrysotoxine, a novel bibenzyl compound, inhibits 6-hydroxydopamine induced apoptosis in SH-SY5Y cells via mitochondria protection and NF-kappaB modulation. Neurochem iInt, 57: 676-689

[64] Song JX, Shaw PC, Wong NS, Sze CW, Yao XS, Tang CW, et al. (2012). Chrysotoxine, a novel bibenzyl compound selectively antagonizes $\mathrm{MPP}(+)$, but not rotenone, neurotoxicity in dopaminergic SH-SY5Y cells. Neurosci Lett, 521: 76-81

[65] Fan WW, Xu FQ, Dong FW, Li XN, Li Y, Liu YQ, et al. (2013). Dendrowardol C, a novel sesquiterpenoid from Dendrobium wardianum Warner. Nat Prod Bioprospect, 3: 89-92

[66] Xiong L, Cao ZX, Peng C, Li XH, Xie XF, Zhang TM, et al. (2013). Phenolic glucosides from Dendrobium aurantiacum var. denneanum and their bioactivities. Molecules, 18: 6153-6160

[67] Arbor CS, Mike LF, Medhane C (2016). Amyloid-beta Alzheimer targets-protein processing, lipid rafts, and amyloid-beta pores. Yale J Biol Med, 89: 5-21

[68] Fulop T, Lacombe G, Cunnane S, Le Page A, Dupuis G, Frost EH, et al. (2013). Elusive Alzheimer's disease: can immune signatures help our understanding of this challenging disease? Part 2: new immune paradigm. Discov Med, 15: 33-42

[69] Lu Y, Kuang M, Hu GP, Wu RB, Wang J, Liu L, et al. (2014). Loddigesiinols G-J: alpha-glucosidase inhibitors from Dendrobium loddigesii. Molecules, 19: 8544-8555

[70] Sun J, Zhang F, Yang M, Zhang J, Chen L, Zhan R, et al. (2014). Isolation of alpha-glucosidase inhibitors including a new flavonol glycoside from Dendrobium devonianum. Nat Prod Res, 28: 1900-1905

[71] Xu Q, Liu Y, Cong YB, Zheng YY, Zhang JP, Cui Y, et al. (2013). Gene Expression and Microarray Investigation of Dendrobium Mixture as Progressive Therapy for the Treatment of Type 2 Diabetes Mellitus. Trop J Pharm Res, 12(2): 195-201

[72] Araszkiewicz A, Gandecka A, Nowicki M, Uruska A, Malińska A, Kowalska K, et al. (2016). Association between small fiber neuropathy and higher skin accumulation of advanced glycation end products in patients with type 1 diabetes. Pol Arch Med Wewn, 126: $847-853$

[73] Pan LH, Feng BJ, Wang JH, Zha XQ, Luo JP (2013). Structural Characterization and Anti-Glycation Activityin Vitroof a Water-Soluble Polysaccharide from Dendrobium huoshanense. J Food Biochem, 37: 313-321

[74] Zha XQ, Li XL, Zhang HL, Cui SH, Liu J, Wang JH, et al. (2013). Pectinase hydrolysis of Dendrobium huoshanense polysaccharide and its effect on protein nonenzymatic glycation. Int J Biol Macromol, 61: $439-447$
Li XL, Xiao JJ, Zha XQ, Pan LH, Asghar MN, Luo JP (2014). Structural identification and sulfated modification of an antiglycation Dendrobium huoshanense polysaccharide. Carbohydr Polym, 106: 247-254

[76] Gong CY, Yu ZY, Lu B, Yang L, Sheng YC, Fan YM, et al. (2014). Ethanol extract of Dendrobium chrysotoxum Lindl ameliorates diabetic retinopathy and its mechanism. Vascul Pharmacol, 62: 134-142

[77] Yu Z, Gong C, Lu B, Yang L, Sheng Y, Ji L, et al. (2015). Dendrobium chrysotoxum Lindl. alleviates diabetic retinopathy by preventing retinal inflammation and tight junction protein decrease. $\mathbf{J}$ Diabetes Res, 2015: 518317

[78] Yu Z, Zhang T, Gong C, Sheng Y, Lu B, Zhou L, et al. (2016). Erianin inhibits high glucose-induced retinal angiogenesis via blocking ERK1/2-regulated HIF-1alpha-VEGF/VEGFR2 signaling pathway. Sci Rep, 6: 34306

[79] Zhang Z, Zhang D, Dou M, Li Z, Zhang J, Zhao X (2016). Dendrobium officinale Kimura et Migo attenuates diabetic cardiomyopathy through inhibiting oxidative stress, inflammation and fibrosis in streptozotocin-induced mice. Biomed Pharmacother, 84: $1350-1358$

[80] Hou SZ, Liang CY, Liu HZ, Zhu DM, Wu YY, Liang J, et al. (2016). Dendrobium officinale prevents early complications in streptozotocin-induced diabetic rats. evidence-based complementary and alternative medicine: Evid-based Compl Alt, 2016: 6385850

[81] Adu-Sarkodie NY (2016). Clinical Management of Diabetes Mellitus in the Older Adult Patient. Current diabetes reviews, In Press

[82] Pereira BI, Akbar AN (2016). Convergence of Innate and Adaptive Immunity during Human Aging. Front Immunol, 7: 445

[83] Meng LZ, Lv GP, Hu DJ, Cheong KL, Xie J, Zhao J, et al. (2013). Effects of polysaccharides from different species of Dendrobium (Shihu) on macrophage function. Molecules, 18: 5779-5791

[84] Wei W, Feng L, Bao WR, Ma DL, Leung CH, Nie SP, et al. (2016). Structure Characterization and Immunomodulating Effects of Polysaccharides Isolated from Dendrobium officinale. J Agric Food Chem, 64: 881-889

[85] Xia L, Liu X, Guo H, Zhang H, Zhu J, Ren F (2012). Partial characterization and immunomodulatory activity of polysaccharides from the stem of Dendrobium officinale (Tiepishihu) in vitro. J Funct Foods, 4: 294-301

[86] He TB, Huang YP, Yang L, Liu TT, Gong WY, Wang $\mathrm{XJ}$, et al. (2016). Structural characterization and immunomodulating activity of polysaccharide from Dendrobium officinale. Int J Biol Macromol, 83: 3441

Cai HL, Huang XJ, Nie SP, Xie MY, Phillips GO, Cui SW (2015). Study on Dendrobium officinale O-acetylglucomannan (Dendronan®): Part IIIImmunomodulatory activity in vitro. Carbohydr Diet Fibre, 5: 99-105 
[88] Zha XQ, Luo JP, Luo SZ, Jiang ST (2007). Structure identification of a new immunostimulating polysaccharide from the stems of Dendrobium huoshanense. Carbohydr Polym, 69: 86-93

[89] Xie SZ, Hao R, Zha XQ, Pan LH, Liu J, Luo JP (2016). Polysaccharide of Dendrobium huoshanense activates macrophages via toll-like receptor 4-mediated signaling pathways. Carbohydr Polym, 146: 292-300

[90] Hsieh YS, Chien C, Liao SK, Liao SF, Hung WT, Yang WB, et al. (2008). Structure and bioactivity of the polysaccharides in medicinal plant Dendrobium huoshanense. Bioorg Med Chem, 16: 6054-6068

[91] Li F, Cui SH, Zha XQ, Bansal V, Jiang YL, Asghar $M N$, et al. (2015). Structure and bioactivity of a polysaccharide extracted from protocorm-like bodies of Dendrobium huoshanense. Int J Biol Macromol, 72: 664-672

[92] Lin J, Chang YJ, Yang WB, Yu AL, Wong CH (2014). The multifaceted effects of polysaccharides isolated from Dendrobium huoshanense on immune functions with the induction of interleukin-1 receptor antagonist (IL-1ra) in monocytes. PLoS One, 9: e94040/94041e94040/94012.

[93] Zha XQ, Zhao HW, Bansal V, Pan LH, Wang ZM, Luo JP (2014). Immunoregulatory activities of Dendrobium huoshanense polysaccharides in mouse intestine, spleen and liver. Int J Biol Macromol, 64: 377-382

[94] Pan LH, Wang J, Ye XQ, Zha XQ, Luo JP (2015). Enzyme-assisted extraction of polysaccharides from Dendrobium chrysotoxum and its functional properties and immunomodulatory activity. Food Sci Technol, 60: 1149-1154

[95] Wang JH, Luo JP, Zha XQ (2010). Structural features of a pectic polysaccharide from the stems of Dendrobium nobile Lindl. Carbohydr Polym, 81: 1-7

[96] Wang JH, Luo JP, Yang XF, Zha XQ (2010). Structural analysis of a rhamnoarabinogalactan from the stems of Dendrobium nobile Lindl. Food Chem, 122: $572-576$

[97] Wang JH, Zha XQ, Luo JP, Yang XF (2010). An acetylated galactomannoglucan from the stems of Dendrobium nobile Lindl. Carbohydr Res, 345: 10231027

[98] Liu XF, Zhu J, Ge SY, Xia LJ, Yang HY, Qian YT, et al. (2011). Orally administered Dendrobium officinale and its polysaccharides enhance immune functions in BALB/c mice. Nat Prod Comm, 6: 867-870
[99] Xie SZ, Liu B, Zhang DD, Zha XQ, Pan LH, Luo JP (2016). Intestinal immunomodulating activity and structural characterization of a new polysaccharide from stems of Dendrobium officinale. Food Funct, 7: 2789-2799

[100] Huang X, Nie S, Cai H, Zhang G, Cui SW, Xie M, et al. (2015). Study on Dendrobium officinale O-acetylglucomannan (Dendronan): Part IV. Immunomodulatory activity in vivo. J Funct Food, 15: 525-532

[101] Yang LC, Lu TJ, Hsieh CC, Lin WC (2014). Characterization and immunomodulatory activity of polysaccharides derived from Dendrobium tosaense. Carbohydr Polym, 111: 856-863

[102] Luo A, Fan Y (2011). Immune stimulating activity of water-soluble polysaccharide fractions from Dendrobium nobile Lindl. Afr J Pharm Pharmacol, 5: 625-631

[103] Tollefson MM, Bruckner AL, Section On D (2014). Atopic dermatitis: skin-directed management. Pediatrics, 134: e1735-1744

[104] Wu KG, Li TH, Chen CJ, Cheng HI, Wang TY (2011). A pilot study evaluating the clinical and immunomodulatory effects of an orally administered extract of Dendrobium huoshanense in children with moderate to severe recalcitrant atopic dermatitis. Int J Immunopathol Pharmacol, 24: 367-375

[105] Fox RI (2005). Sjögren's syndrome. The Lancet, 366: 321-331

[106] Lin X, Shaw PC, Sze SC, Tong Y, Zhang Y (2011). Dendrobium officinale polysaccharides ameliorate the abnormality of aquaporin 5, pro-inflammatory cytokines and inhibit apoptosis in the experimental Sjogren's syndrome mice. Int Immunopharmacol, 11: 2025-2032

[107] Xiang L, Stephen Sze CW, Ng TB, Tong Y, Shaw PC, Sydney Tang CW, et al. (2013). Polysaccharides of Dendrobium officinale inhibit TNF- $\alpha$-induced apoptosis in A-253 cell line. Inflammation Res, 62: 313-324

[108] Xiao L, Ng TB, Feng YB, Yao T, Wong JH, Yao RM, et al. (2011). Dendrobium candidum extract increases the expression of aquaporin-5 in labial glands from patients with Sjogren's syndrome. Phytomedicine, 18: 194-198

[109] Yang D, Liu LY, Cheng ZQ, Xu FQ, Fan WW, Zi CT, et al. (2015). Five new phenolic compounds from Dendrobium aphyllum. Fitoterapia, 100: 11-18 